\title{
Natural Disasters, Political Risk and Insurance Market Development
}

\author{
Chun Ping Chang ${ }^{\mathrm{a}}$ and Aziz N. Berdiev ${ }^{\mathrm{b}}$ \\ a Department of Marketing Management, Shih Chien University, Kaohsiung 845, Taiwan. \\ E-mail: cpchang@mail.kh.usc.edu.tw \\ ${ }^{\mathrm{b}}$ Department of Economics, Bryant University, Smithfield, RI 02917, U.S.A. \\ E-mail: aberdiev@bryant.edu
}

We examine the relationship between natural disasters, political risk and insurance market development in a panel of 39 countries over the period 1984-2009 using a dynamic panel two-step system generalised method of moments model. We provide evidence that the incidences of natural disasters and deaths caused by natural disasters lead to greater total insurance, as well as life insurance and non-life insurance consumption. We also find that countries with lower levels of political risk experience higher insurance consumption. The incidences of natural disasters and deaths attributable to natural disasters contribute to insurance market development under the tenure of a government with lower levels of political risk. We therefore emphasise that natural disasters, political risk and their interaction effects are important determinants of insurance market development.

The Geneva Papers (2013) 38, 406-448. doi:10.1057/gpp.2013.14

Keywords: natural disasters; political risk; insurance market development; panel data

Article submitted 31 July 2012; accepted 27 March 2013; published online 29 May 2013

\section{Introduction}

A considerable amount of literature has been devoted to understanding the consequences of natural disasters. This is because natural disasters have caused substantial economic damages, and, more importantly, these economic costs following a natural disaster have been significantly increasing in the past several decades. For example, worldwide economic costs from natural disasters were approximately US $\$ 53.6$ billion in the 1950s, whereas these economic damages reached roughly US $\$ 778.3$ billion by the 1990s. ${ }^{1,2}$ Furthermore, natural disasters caused about US $\$ 370$ billion in economic costs in 2011 alone. ${ }^{3}$ As such, natural disasters contribute to vital consequences for the local economy.

Given that natural disasters have caused significant worldwide economic damages, the 1992 United Nations Framework Convention on Climate Change has emphasised

\footnotetext{
${ }^{1}$ Kunreuther (2008); Michel-Kerjan and Kousky (2010).

${ }^{2}$ Schwarze and Wagner (2004) also provide a detailed analysis on the economic costs following natural disasters by each decade, from the 1950s to the end of 1990s.

${ }^{3}$ Swiss Reinsurance Company (2012).
} 
the important role of insurance industries in disaster assistance in local economies. ${ }^{4}$ More recently, the 2005 Hyogo Framework for Action highlights the urgency to advance the expansion of insurance markets to finance risk following a natural disaster. ${ }^{4} \mathrm{Cummins}$ and $\mathrm{Mahul}^{4}$ argue that insurance market development is particularly important, because governments frequently redirect finances and resources from development projects for recovery efforts following a natural disaster. The political environment of a country may also considerably influence insurance market development across countries.

Hence, the primary purpose of this paper is to investigate the relationship between natural disasters, political risk and insurance consumption across countries. First, we ask, do natural disasters contribute to insurance market development? More specifically, we examine whether the incidences of natural disasters impact insurance consumption. We also assess whether deaths caused by natural disasters influence the demand for insurance. Since natural disasters cause significant economic and human losses in a local economy, households may invest in appropriate protective measures (i.e. purchase insurance policies) to acquire financial security. For example, Kunreuther ${ }^{5}$ indicates that "the occurrence of a disaster causing damage to one's home is likely to have a significant impact on the demand for insurance" (p. 176).

Second, we investigate whether the development of insurance markets varies under the tenure of a government with different levels of political risks. The literature providing evidence that the quality of the political environment is an important determinant of insurance market development across countries has grown significantly. ${ }^{6}$ Moreover, Hussels et al. ${ }^{7}$ argue that the "functioning of a working legal system and the protection it may afford policyholders is a major determinant of insurance market development" (p. 264). Thus, higher levels of political risk in a country may possibly impact the investment activities of international companies, because it raises the risk premium of an investment venture. ${ }^{8,9}$ It is therefore possible that countries with higher levels of political risk experience lower insurance consumption.

Third, we analyse whether the occurrences of natural disasters, and deaths caused by natural disasters, influence insurance market development under the tenure of a government with different levels of political risk. In particular, we estimate the interaction effects of natural disaster variables and political risk on insurance consumption across countries. Our argument follows Oh and Reuveny, ${ }^{10}$ who indicate that "disasters may increase political risk, and political risk may indicate how well the economy can respond to disasters and recover" (p. 244). ${ }^{11}$ Since natural disasters and political risk may potentially influence each other, ${ }^{10}$ we also argue that natural

\footnotetext{
${ }^{4}$ Cummins and Mahul (2009).

${ }^{5}$ Kunreuther (1996).

${ }^{6}$ Ward and Zurbruegg (2002); Esho et al. (2004); Feyen et al. (2011).

${ }^{7}$ Hussels et al. (2005).

${ }^{8}$ Busse and Hefeker (2007).

${ }^{9}$ For example, Busse and Hefeker (2007) find that the level of political risk in a country significantly influences the inflows of foreign direct investment.

${ }^{10}$ Oh and Reuveny (2010).

${ }^{11}$ Oh and Reuveny (2010) investigate the interaction effects of natural disasters and political risk on international trade.
} 
disasters and political risk may possibly interact in impacting insurance market development across countries.

Finally, we examine the determinants of insurance market development using panel data for 39 countries. The analysis is based upon data recorded annually over the period of 1984-2009. ${ }^{12}$ To account for possible heterogeneity in the dependent variable, we distinguish between life insurance and non-life insurance consumption in the empirical analysis. Hence, we use life insurance premiums, non-life insurance premiums and total insurance premiums as a percentage of gross domestic product (GDP) (insurance penetration) and (log) per capita, in constant US\$ (insurance density) to represent insurance market development. In the interest of robustness, we use five measures of natural disasters in the empirical analysis, namely, floods, earthquakes, windstorms, epidemics and climatological disasters.

We employ a dynamic panel two-step system generalised method of moments (GMM) estimator developed by Arellano and Bond, ${ }^{13}$ Arellano and Bover, ${ }^{14}$ and Blundell and Bond, ${ }^{15}$ who proposed a methodology to generate consistent, efficient and robust estimators in a dynamic panel data model. ${ }^{16}$ The dynamic panel GMM methodology "exploits the time-series variation in the data, accounts for unobserved country-specific effects, allows for the inclusion of lagged dependent variables as regressors, and controls for endogeneity of all the explanatory variables" ${ }^{17}$ (p. 264). We employ panel data analysis to account for the presence of heterogeneity in the estimated parameters and dynamics across countries. ${ }^{18}$

To anticipate our results, we find that natural disasters are important determinants of insurance market development. More specifically, we find that the occurrences of natural disasters and deaths caused by natural disasters contribute to higher total insurance, as well as life insurance and non-life insurance consumption. We also provide evidence that countries with lower levels of political risk are associated with insurance market development. Furthermore, the incidences of natural disasters and deaths attributable to natural disasters lead to higher insurance consumption under the tenure of a government with lower levels of political risk. In effect, these results imply that a rise in the political risk level of a country mitigates the beneficial effect of natural disaster variables on insurance market development.

Overall, we provide evidence that the incidences of natural disasters and death caused by natural disasters persuade individuals to invest in necessary protective measures, that is, purchase insurance products. However, we discover that not all occurrences of natural disasters and natural disaster deaths stimulate the demand for

\footnotetext{
${ }^{12}$ We collect annual data for a panel of 39 countries over the period 1984-2009 in the empirical analysis primarily on the basis of data availability.

13 Arellano and Bond (1991).

14 Arellano and Bover (1995).

15 Blundell and Bond (1998).

${ }^{16}$ We conduct a number of specification tests in a dynamic panel two-step system GMM model, including the Hansen and Arellano-Bond tests, to ensure that the econometric model produces consistent, efficient and robust estimates.

${ }^{17}$ Beck et al. (2000).

18 Baltagi (1995).
} 
life insurance and non-life insurance policies. Since floods, earthquakes, windstorms, epidemics and climatological disasters are associated with different scales of economic and human losses, it is perhaps not surprising that not all natural disasters induce residents to purchase insurance products to secure financial protection. In summary, our results provide evidence that natural disasters, political risk and their interaction effects are fundamental determinants of insurance consumption across countries.

The remainder of the paper is structured as follows. In the next section, we provide a general background on natural disasters and insurance market development. The section after that describes the determinants of insurance market development in accordance with the previous literature. Then, the definitions and data sources of all the variables used in the empirical analysis are provided. In the subsequent section, we detail the econometric model employed in the estimation. The penultimate section presents the empirical results for the baseline and the extended specifications, while the final section summarises the major findings.

\section{General background}

The literature documents that natural disasters have substantial implications for economic and political stability. This is perhaps not surprising given that natural disasters are significantly associated with a destruction of physical and human capital in a country. ${ }^{19}$ For example, natural disasters destroy water pipelines, harvests, animal life, housing, transportation and communication networks, trade, and energy transit routes in a domestic economy. ${ }^{20}$

Furthermore, the empirical work of $\mathrm{Noy}^{21}$ investigates the macroeconomic implications of natural disasters and finds that natural disasters adversely affect a country's domestic production. In addition, Oh and Reuveny ${ }^{10}$ show that natural disasters negatively impact international trade and, therefore, emphasise that these severe natural occurrences may contribute to a slowdown in economic globalisation across nations. More recently, Strobl ${ }^{22}$ examines the macroeconomic consequences of natural disasters in developing economies and discovers that natural disasters significantly reduce economic growth. ${ }^{23}$ As a result, natural disasters considerably deteriorate the welfare of society.

According to Hussels et al., ${ }^{7}$ the key role of insurance markets is to finance risks by providing "individuals and businesses with coverage against specified contingencies, by redistributing losses among the pool of policyholders" (p. 259). Since natural disasters cause significant economic and human losses, insurance companies may

\footnotetext{
${ }^{19}$ See, for example, Noy (2009); Noy and Vu (2010); Oh and Reuveny (2010); Strobl (2012).

${ }^{20}$ See, for example, Ember and Ember (1992); Miguel et al. (2004); Bhavnani (2006); Brancati (2007); Noy (2009); Oh and Reuveny (2010).

${ }^{21}$ Noy (2009).

22 Strobl (2012).

${ }^{23}$ It is important to note that these natural disaster losses differ greatly across governments. For example, Kahn (2005) finds that countries with higher income, democratic institutions and stronger governments experience fewer natural disaster deaths. Also, Toya and Skidmore (2007) find that nations with higher measures of development suffer less natural disaster losses.
} 
supply coverage against these unforeseen events. Hence, it is critically important for households and businesses to obtain insurance in order to mitigate natural disaster losses. ${ }^{24}$ Athavale and Avila $^{25}$ explain that individuals may sustain significant monetary loses if they select not to insure against these unexpected shocks.

Thus, it is likely that individuals and businesses purchase insurance to acquire financial security, since natural disasters cause substantial economic costs in a country. ${ }^{26}$ Kunreuther ${ }^{5}$ therefore argues that the incidence of natural disasters may considerably influence the demand for insurance in a local economy. Furthermore, Arnold ${ }^{27}$ emphasises that insurance industries "form a critical part of a comprehensive disaster risk management strategy, and have the potential to play an important role in disaster risk reduction" (p. 3). As such, it is imperative that households invest in protective measures prior to a natural disaster by participating in insurance programmes. ${ }^{28}$

While natural disasters cause substantial economic damages and adversely impact the domestic economy, they are commonly described as a low-probability event. ${ }^{29}$ Thus, many individuals often elect not to purchase insurance because the probability that a natural disaster occurs is significantly low. ${ }^{30}$ In this context, residents neglect to account for the impending natural disaster losses, since they estimate that natural disasters are low-probability events. ${ }^{24}$ As such, Kunreuther ${ }^{5}$ indicates that the general public may not invest in appropriate protective measures because they assume that the cost of the insurance exceeds the benefits of protective measures.

Also, Anderson ${ }^{31}$ suggests that households decide not to insure against natural disasters, since these negative shocks are "confined to relatively concentrated areas" (p. 579). According to Schwarze and Wagner" ${ }^{30}$ the "systematic underestimation and high discounting of the full extent of the risk of rare disasters by those people likely to be affected" explains the considerably low demand for natural disaster insurance ( $p$. $3)^{32}$ As a result, Kunreuther ${ }^{29}$ explains that only a small number of residents willingly implement "cost-effective loss-reduction measures" before a natural disaster (p. 912). ${ }^{33}$ It is also possible that the accessibility to international and domestic assistance may contribute to the lack of demand for insurance across countries.

Besides, the literature provides ample evidence that the convenience of foreign and local aid clarifies the disinclination of the general population to invest in effective protective policy measures against natural disasters. ${ }^{34}$ In this context, Coate ${ }^{35}$ argues

${ }^{24}$ Kunreuther (1984).

${ }^{25}$ Athavale and Avila (2011).

${ }^{26}$ Zeckhauser (1995).

${ }^{27}$ Arnold (2008).

${ }^{28}$ Kriesel and Landry (2004).

${ }^{29}$ Kunreuther (2008).

${ }^{30}$ Schwarze and Wagner (2007).

31 Anderson (1974).

${ }^{32}$ Kunreuther (1996) also suggests that "underestimation of probability" and "high discount rates" describe the motives residents may not invest in protective measures prior to a natural disaster.

${ }^{33}$ In addition, Kunreuther $(1984,1996,2008)$ provides a great discussion on the reasons why individuals underinsure from natural disaster losses.

${ }^{34}$ See, for example, Coate (1995); Kunreuther (1996); Schwarze and Wagner (2007).

35 Coate (1995). 
that this "charitable assistance" causes significant "inequities and inefficiencies" in the domestic economy (p. 47). ${ }^{36}$ Also, Raschky et al. ${ }^{37}$ argue that the institutional structure of government assistance programmes considerably impacts insurance demand. Furthermore, Kunreuther ${ }^{5}$ and Schwarze and Wagner $^{30}$ note that many households presume and anticipate assistance following a natural disaster and, therefore, decide not to purchase insurance.

However, it is important to note that many households are generally more likely to purchase natural disaster insurance following an occurrence of a natural disaster as compared with before this negative shock. ${ }^{38}$ This is because the incidence of the natural disaster becomes "more salient in people's minds due to the availability bias and/or there is more concern by individuals about the event and a desire to invest in protection" 39 (p. 94). Moreover, Gennaioli and Shleifer ${ }^{40}$ explain that there is preferred recollection of information, since the likelihood that a natural disaster occurs is low"representativeness heuristics" (p. 1430). Nevertheless, this negative shock develops into an account of an uncertain event as soon as it takes place, which, in turn, causes many individuals to purchase natural disaster insurance. ${ }^{40}$

Moreover, Kunreuther ${ }^{41}$ discusses four important "cost bearing" methods to secure protection from natural disaster losses: (1) "total federal responsibility", (2) "self insurance by the homeowner", (3) "required insurance protection", and (4) "land-use restrictions and building codes" (p. 287). Nevertheless, Kunreuther ${ }^{41}$ suggests that an adequate protective measure entails a complete natural disaster insurance protection complemented with land-use and building codes regulations in order to mitigate economic damages caused by natural disasters. According to Gerber, ${ }^{42}$ insufficient and ineffective protective measures prior to a natural disaster may exacerbate the detrimental consequences of natural disasters.

\section{Determinants of insurance market development}

The literature has documented that national income is a critically important determinant of insurance consumption in a country. ${ }^{43}$ More specifically, higher income is associated with insurance market development, as, for example, argued by

${ }^{36}$ Furthermore, Coate (1995) explains that the unwillingness of the general public to invest in protective measures (i.e. purchase natural disaster insurance) from natural disasters is considerably associated with the conventional charity of the population concerning those individuals that are greatly affected by natural disasters in the United States.

${ }^{37}$ Raschky et al. (2013).

${ }^{38}$ Cutler and Zeckhauser (2004); Kunreuther and Pauly (2005).

${ }^{39}$ Kunreuther and Pauly (2005).

${ }^{40}$ Gennaioli and Shleifer (2010).

${ }^{41}$ Kunreuther (1974).

42 Gerber (2007).

${ }^{43}$ Hammond et al. (1967); Beenstock et al. (1986); Truett and Truett (1990); Browne and Kim (1993); Outreville (1996); Enz (2000); Browne et al. (2000); Ward and Zurbruegg (2002); Beck and Webb (2003); Esho et al. (2004); Hussels et al. (2005); Hwang and Greenford (2005); Li et al. (2007); Feyen et al. (2011). 
Browne et $a l .{ }^{44}$ This is the case because greater income enables households to purchases insurance to acquire financial protection. ${ }^{45}$ Furthermore, Li et al. ${ }^{46}$ suggest that a "large income results in a greater loss of expected utility for the dependents in the event of the income earner's death" and thus increases life insurance consumption in an economy (p. 640).

Next, several studies have emphasised the significance of inflation rates as an imperative economic factor in insurance market determination. ${ }^{47}$ In particular, a rising inflation rate is anticipated to reduce the demand for insurance products. Outreville ${ }^{48}$ therefore indicates that insurance products may not effectively provide for the welfare of the general population in high inflation-rate economies. Hussels et al. ${ }^{7}$ explain that higher inflation rates reduce the total value of all forthcoming repayments from the insurance industry. Hence, higher inflation rates decrease the benefits of insurance products and, therefore, inhibit the purchase of insurance policies in a country. ${ }^{49,50}$

It is also imperative to account for the real interest rates in an economy. However, the literature has not established the relationship between real interest rates and insurance market development. ${ }^{51}$ Beck and $\mathrm{Webb}^{52}$ argue that higher real interest rates are associated with greater insurance consumption. This is the case as rising real interest rates contribute to greater investment returns for the insurance companies, which, in turn, may supply higher profitability to their customers. ${ }^{52}$ Li et al. ${ }^{46}$ also explain that higher real interest rates may reduce the price of insurance policies, and, thus, increase insurance consumption. However, rising real interest rates may also induce prospective purchasers of insurance products to decrease "their number of purchases" due to expectations of greater investment returns. ${ }^{46,53}$

Furthermore, the literature has emphasised the critical impact of government provisions, i.e. government spending on social welfare, on insurance consumption. ${ }^{54}$ It is anticipated that households normally decrease their investment in protective measures (i.e. purchase life insurance) given that the government is allocating more resources towards social welfare programmes. ${ }^{55}$ Nevertheless, the relationship between government expenditures on social welfare and insurance market development is

${ }^{44}$ Browne et al. (2000).

${ }^{45}$ Feyen et al. (2011).

${ }^{46} \mathrm{Li}$ et al. (2007).

${ }^{47}$ Browne and Kim (1993); Outreville (1996); Browne et al. (2000); Ward and Zurbruegg (2002); Beck and Webb (2003); Esho et al. (2004); Hussels et al. (2005); Li et al. (2007); Feyen et al. (2011).

${ }^{48}$ Outreville (1996).

${ }^{49}$ Ward and Zurbruegg (2002).

${ }^{50}$ Ward and Zurbruegg (2002) also note that rising inflation rates are considerably linked with macroeconomic volatility, which, in turn, devalues the benefits of financial resources, that is, insurance products.

${ }^{51}$ Outreville (1996); Beck and Webb (2003); Li et al. (2007); Feyen et al. (2011).

${ }^{52}$ Beck and Webb (2003).

${ }^{53}$ Feyen et al. (2011) explain that the relationship between real interest rates and insurance consumption is often not straightforward since the supply and demand for insurance policies are extremely intricate.

${ }^{54}$ Browne and Kim (1993); Outreville (1996); Ward and Zurbruegg (2002); Beck and Webb (2003); Zietz (2003); Hussels et al. (2005); Hwang and Greenford (2005); Li et al. (2007); Feyen et al. (2011).

55 Ward and Zurbruegg (2002); Hussels et al. (2005). 
unclear. ${ }^{56}$ For example, Browne and $\mathrm{Kim}^{57}$ provide evidence that government spending on social welfare is significantly associated with higher demand for life insurance. $^{58}$

Moreover, it is significant to control for the dependency ratio in the analysis of insurance consumption. ${ }^{59}$ More specifically, the primary goal of acquiring life insurance is to secure financial protection for dependents in the event of an untimely death of the primary wage earner as first documented by Hammond et al. ${ }^{60,61}$ However, Beck and $\mathrm{Webb}^{52}$ argue that a rise in the dependency ratio suggests that a sizeable proportion of the general public are extremely youthful to invest in savings for retirement, which, in turn, leads to a decrease in demand for savings products, that is, life insurance policies.

In addition, it is important to account for the political environment of a country in the analysis of insurance consumption. ${ }^{62}$ Ward and Zurbruegg ${ }^{49}$ emphasise that the legal environment in the local economy is an important factor of the growth of life insurance premiums. Similarly, Esho et al. ${ }^{63}$ explain the significance of the legal environment in explaining property-casualty insurance. This is the case because countries that experience a high quality of legal environment provide the general population with protection against the inappropriate activities of insurance corporations. ${ }^{49}$ As such, we anticipate that countries with low levels of political risk experience greater insurance market development.

Finally, it is imperative to consider the interaction effects of natural disasters and political risk, as these two factors may possibly interact in influencing insurance market development across countries. Oh and Reuveny ${ }^{10}$ argue that natural disasters and political risk may possibly influence each other. It is possible that the occurrence of natural disasters leads to political unrest in a country. For example, Olson and Drury, ${ }^{64}$ and Drury and Olson ${ }^{65}$ find that natural disasters increase political instability in a society, while Bhavnani, ${ }^{66}$ Brancati, $^{67}$ and Nel and Righarts ${ }^{68}$ show that natural

${ }^{56}$ For a more comprehensive discussion on the relationship between governments' expenditures on social welfare and insurance consumption, see Browne and Kim (1993) and Zietz (2003).

${ }^{57}$ Browne and Kim (1993).

${ }^{58}$ Browne and Kim (1993) indicate that these government benefits denote "assets which individuals protect against premature loss" (p. 627).

${ }^{59}$ Hammond et al. (1967); Campbell (1980); Beenstock et al. (1986); Truett and Truett (1990); Browne and Kim (1993); Outreville (1996); Ward and Zurbruegg (2002); Beck and Webb (2003); Zietz (2003); Hussels et al. (2005); Hwang and Greenford (2005); Li et al. (2007); Feyen et al. (2011).

${ }^{60}$ Hammond et al. (1967).

${ }^{61}$ Also, Campbell (1980) provides a detailed theoretical analysis on the demand for life insurance, particularly households' efficient response to the potential early death of the primary wage earner.

${ }^{62}$ Browne et al. (2000); Ward and Zurbruegg (2002); Esho et al. (2004); Hussels et al. (2005); Feyen et al. (2011).

${ }^{63}$ Esho et al. (2004).

64 Olson and Drury (1997).

65 Drury and Olson (1998).

${ }^{66}$ Bhavnani (2006).

${ }^{67}$ Brancati (2007).

${ }^{68} \mathrm{Nel}$ and Righarts (2008). 
disasters intensify intrastate conflict in a country. Berrebi and Ostwald ${ }^{69}$ also find that natural disasters increase terrorism occurrences. Moreover, Chang and Berdiev ${ }^{70}$ find that natural disasters increase the likelihood that a government is replaced.

As such, political unrest heightens uncertainty about the political future of the government (Klomp and de Haan, 2009). It is therefore possible that the occurrences of natural disasters contribute to lower insurance consumption under the tenure of a government with high levels of political risk. This is because political instability and powerful conflicts contribute to "uncertainty about future property rights which deters productive activities and, in particular, investment decisions". ${ }^{71}(\mathrm{p} .19)$ Also, the general population may be unable to rely on insurance companies to provide financial protection in the event that a natural disaster causes the untimely death of the primary wage earner or contributes to considerable economic costs in countries with higher levels of political risk. Feyen et $\mathrm{al}^{45}$ highlight the value of the legal environment in the local economy, as it expands the reliability and trustworthiness of insurance companies. Hence, individuals are less likely to invest in protective measures against natural disasters (i.e. purchase insurance policies) to attain financial protection in countries with higher levels of political risk.

It is thus possible that the incidences of natural disasters and death attributed to natural disasters impact insurance consumption differently as the political risk level of a country rises. In particular, a rise in political risk may contribute to unfavourable environment for insurance market development, especially following a natural disaster. In our view, this is the case for responsive and unresponsive governments. ${ }^{72}$ Even an extremely responsive government is unable to provide effective natural disaster relief management. This is because governments may react to the occurrence of a natural disaster by commanding central planning in the allocation of public resources. In this context, Sobel and Leeson ${ }^{73}$ argue that "central planning cannot effectively coordinate decision making among numerous and dispersed individuals with different endowments, wants, and needs" (p. 529). In the United States, for example, Sobel and Leeson ${ }^{74}$ detail the incapacity of the Federal Emergency Management Agency to provide effective natural disaster assistance following Hurricane Katrina in 2005. It is therefore perhaps not surprising that individuals anticipate international assistance following a natural disaster, especially in countries with higher levels of political risk.

\section{Data}

The primary goal of the present paper is to examine the relationship between natural disasters, political risk and insurance market development. The analysis is based upon

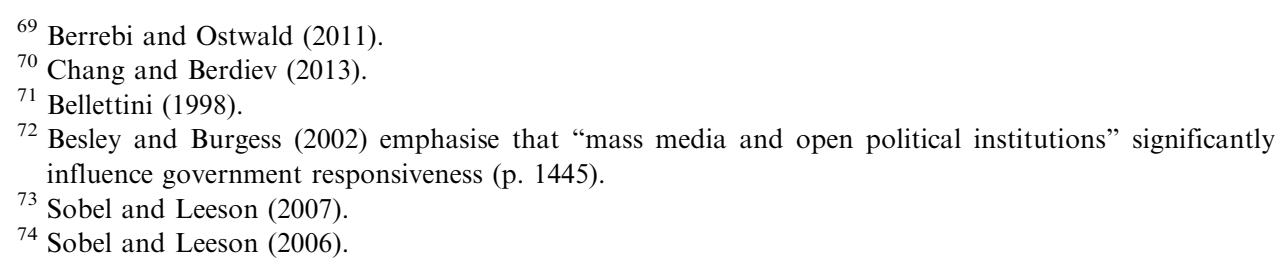


data recorded annually over the period 1984-2009 in a panel of 39 countries. The specific sets of countries are Algeria, Australia, Austria, Belgium, Canada, Colombia, Denmark, Egypt, Finland, France, Greece, India, Indonesia, Ireland, Israel, Italy, Japan, Kenya, Luxembourg, Malaysia, Mexico, Morocco, the Netherlands, New Zealand, Norway, the Philippines, Portugal, Singapore, South Africa, South Korea, Spain, Sweden, Switzerland, Taiwan, Thailand, Turkey, the United Kingdom, the United States of America and Venezuela. The data is obtained from several sources, namely the Emergency Events Database ${ }^{75}$ of the Centre for Research on the Epidemiology of Disasters (CRED), the International Country Risk Guide, ${ }^{76}$ Swiss Reinsurance Company ${ }^{77}$ and the World Bank's World Development Indicators (2011).

The data on life insurance premiums, non-life insurance premiums and total insurance premiums comes from Swiss Reinsurance Company. ${ }^{77}$ To effectively characterise insurance market development across countries, we use life insurance premiums, non-life insurance premiums and total insurance premiums as a percentage of GDP (insurance penetration) and (log) per capita, in constant US\$ (insurance density). More specifically, we calculate (1) (log) real life insurance premiums per capita (life insurance density), (2) (log) real non-life insurance premiums per capita (non-life insurance density), (3) (log) real total insurance premiums per capita (total insurance density), (4) life insurance premiums as a percentage of GDP (life insurance penetration), (5) non-life insurance premiums as a percentage of GDP (non-life insurance penetration), and (6) total insurance premiums as a percentage of GDP (total insurance penetration). ${ }^{78}$

Next, the data on natural disasters is taken from the Emergency Events Database (EM-DAT, 2011) of the CRED. This database records information using an extensive range of nationwide sources that detail and give an account of natural disaster occurrence since $1900 .{ }^{79,80}$ As such, this database classifies a "disaster as a natural situation or event which overwhelms local capacity, necessitating a request for external assistance" 21 (p. 222). More specifically, the EM-DAT registers a natural disaster if it fulfils at least one of the following conditions: (1) "ten or more people reported killed"; (2) "100 or more people reported affected"; (3) "declaration of a state of emergency"; or (4) "a call for international assistance". Ramcharan ${ }^{81}$ explains that

\footnotetext{
${ }^{75}$ Emergency Events Database (2011).

${ }^{76}$ International Country Risk Guide (2010).

${ }^{77}$ Swiss Reinsurance Company (2011).

${ }^{78}$ Since the data on the insurance premiums are reported in local currency units, Swiss Reinsurance Company uses the average period exchange rate to convert all time series into U.S. dollars. Next, we use the total population and U.S. consumer price index data from the World Bank's World Development Indicators (2011) to transform the data on insurance premiums into real per capita variables (insurance density). We also use the data on GDP that come from the World Bank's World Development Indicators (2011) to express the insurance premiums variables as a percentage of GDP (insurance penetration).

79 Raddatz (2007); Noy (2009); Oh and Reuveny (2010).

${ }^{80}$ Noy (2009) explains that these sources consist of non-governmental institutions, United Nations organisations, research institutions, insurance corporations and the media.

${ }^{81}$ Ramcharan (2007).
} 
"these relatively low thresholds ensure that most disasters are recorded in the database" (p. 34). Furthermore, this database has been used extensively in recent studies on natural disasters. ${ }^{82}$

To ensure the robustness of our results, we use five measures of natural disaster variables in the empirical analysis, namely, floods, earthquakes, windstorms, epidemics and climatological disasters. To measure the incidences of natural disasters, we employ the number of floods, earthquakes, windstorms, epidemics and climatological disasters that occurred in a particular year $t$ and country $i$. To effectively quantify natural disaster deaths, we utilise the total number of "persons confirmed as dead and persons missing and presumed dead" caused by floods, earthquakes, windstorms, epidemics and climatological disasters in a particular year $t$ and country $i$. As such, we use five natural disaster variables to evaluate the occurrences (number) of natural disasters across countries. In addition, we employ five natural disaster variables to assess natural disaster deaths across countries.

The discussion in the previous section on the determinants of insurance market development suggests incorporating additional explanatory variables to obtain efficient estimation results. As such, we follow previous literature and employ real GDP per capita (constant 2000 US\$ and transformed into natural logarithms), annual percentage change in consumer price index to denote the inflation rate, lending interest rates (adjusted for inflation by the GDP deflator) to represent the real interest rates, government health expenditure as a percentage of GDP to measure government provision on social welfare, ${ }^{83}$ and the ratio of the population under the age of 15 to the population aged 15-65 to capture the dependency ratio. All these variables are extracted from the World Bank's World Development Indicators (2011).

The data on political risk comes from the International Country Risk Guide, ${ }^{76}$ which constructs an index of political risk covering 12 main dimensions: government stability (0-12), socioeconomic conditions $(0-12)$, investment profile $(0-12)$, internal conflict $(0-12)$, external conflict $(0-12)$, corruption $(0-6)$, military in politics $(0-6)$, religious tensions (0-6), law and order (0-6), ethnic tensions (0-6), democratic accountability (0-6), and bureaucracy quality $(0-4) .{ }^{84}$ These sub-indexes are, in turn, aggregated into one single index of political risk. The political risk index ranges between 0 and 100, where lower values represent greater political risk. ${ }^{85}$ The definitions, data sources, predicted signs and summary statistics for all the variables are displayed in Table A1 (in Appendix).

\footnotetext{
${ }^{82}$ See, for example, Kahn (2005); Bhavnani (2006); Raddatz (2007); Ramcharan (2007); Nel and Righarts (2008); Noy (2009); Oh and Reuveny (2010); Strobl (2012); Chang and Berdiev (2013).

${ }^{83}$ Previous literature has also employed social security expenditures to capture government provision on social welfare (see, for example, Li et al., 2007). However, using social security expenditures would have reduced the number of observations in our empirical analysis.

${ }^{84}$ The weights for each sub-index that is used to construct the political risk index are in parenthesis.

${ }^{85}$ For a detailed analysis on the political risk index, including construction and methodology, see International Country Risk Guide (2010).
} 


\section{Model}

Consider the following dynamic panel data model, which improves and corrects many of the shortcomings resulting from the cross-sectional and static panel data methodology:

$$
y_{i t}=\alpha y_{i, t-1}+\beta \text { disaster }_{i t}+\delta^{\prime} x_{i t}+\mu_{i}+\eta_{t}+\varepsilon_{i t} i=1, \ldots, N \quad t=1, \ldots, T,
$$

where $y_{i t}$ is the dependent variable that represents insurance density (life insurance density, non-life insurance density and total insurance density) and insurance penetration (life insurance penetration, non-life insurance penetration and total insurance penetration). The explanatory variable, disaster, corresponds to the five measures of natural disasters, specifically (the number of and deaths caused by) floods, earthquakes, windstorms, epidemics and climatological disasters. $X$ denotes a set of independent variables, which includes real GDP, the inflation rate, the real interest rate, health expenditure and the dependency ratio; $\mu_{i}$ are the unobserved countryspecific effects, $\eta_{t}$ are the time-specific effects, $\varepsilon_{i t}$ is the disturbance term, and $i$ and $t$ represent the country and time period, respectively.

However, the lagged dependent variable is correlated with the error term when the ordinary least square model is employed in the estimation. We therefore use a dynamic panel GMM model developed by Arellano and Bond, ${ }^{13}$ Arellano and Bover, ${ }^{14}$ and Blundell and Bond, ${ }^{15}$ who proposed a methodology to generate consistent and efficient estimators in dynamic panel data models. More specifically, we firstdifference Eq. (1) to eliminate the country-specific effects, and, thus, generate the firstdifference $\mathrm{GMM}^{13}$ model as follows:

$$
\Delta y_{i t}=\alpha \Delta y_{i, t-1}+\beta \Delta \text { disaster }_{i t}+\delta^{\prime} \Delta x_{i t}+\left(\eta_{t}-\eta_{t-1}\right)+\Delta \varepsilon_{i t},
$$

where $\Delta$ denotes first-difference. The limitation of the first-difference GMM estimator is that it eliminates "the pure cross-country dimension of the data" and reduces "the signal-to-noise ratio, thereby exacerbating measurement error biases". ${ }^{17}$ (p. 278) Arellano and Bover, ${ }^{14}$ and Blundell and Bond ${ }^{15}$ thus propose the system GMM estimator that stacks the level and difference equations, and uses the lagged levels of the series $\left(y_{i t}, x_{i t}\right)$ as instruments for first-differenced variables $\left(\Delta y_{i, t-1}, \Delta x_{i t}\right)$, and lagged first-differenced of the series $\left(y_{i t-1}, x_{i t-1}\right)$ as instruments for the level variables. $^{86}$

As such, we generate the dynamic two-step system GMM estimators, where "the error terms are assumed to be both independent and homoskedastic, across countries and over time" in the first step and, subsequently, "the residuals obtained in the first step are used to construct a consistent estimate of the variance-covariance matrix,

\footnotetext{
${ }^{86} \mathrm{We}$ employ the second lag of the variable inflation rate as an instrument. Also, we utilise year fixed effects as standard instruments in our model. In the earlier draft of this paper, we also employed all available lagged values of independent variables as instruments (as in Beck et al., 2000). As a way to minimise the number of instruments in the regressions, we collapse the matrix of instruments as suggested in Roodman (2009). Overall, the results continue to support our findings. All these results are available upon request.
} 
thus relaxing the assumptions of independence and homoskedasticity" in the second step. $^{17}$ (p. 278)

Furthermore, we extend Eq. (2) and examine the impact of political risk and the interaction effects of natural disasters and political risk on insurance market development. Hence, we investigate the following model:

$$
\begin{aligned}
\Delta y_{i t}= & \alpha \Delta y_{i, t-1}+\beta \Delta \text { disaster }_{i t}+\lambda \Delta\left[\text { disaster }_{i t} \times \text { risk }_{i t}\right] \\
& +\rho \Delta \text { risk }_{i t}+\delta^{\prime} \Delta x_{i t}+\left(\eta_{t}-\eta_{t-1}\right)+\Delta \varepsilon_{i t},
\end{aligned}
$$

where the explanatory variable, risk, represents the political risk of a country and $\left[\right.$ disaster $_{i t} \times$ risk $\left._{i t}\right]$ captures the interaction effects of natural disasters and political risk. To ensure that our specified econometric model produces consistent, efficient and robust estimates, we conduct a number of specification tests: the Hansen and Arellano-Bond tests. The Hansen test of over-identification restrictions tests the validity of the instruments, whereas the Arellano-Bond tests of first-order and secondorder autocorrelation tests that the estimated residuals do not produce first-order and second-order serial correlation, respectively. In what follows, we provide the dynamic panel two-step system GMM regression estimates for Eqs (2) and (3) and discuss these empirical results.

\section{Empirical results}

\section{Baseline specification}

The GMM regression estimates for the dependent variables' total insurance density (columns 1-5), life insurance density (columns 6-10) and non-life insurance density (columns 11-15) are presented in Table 1. In Table 2, we provide the GMM regression estimates for the dependent variables' total insurance penetration (columns 1-5), life insurance penetration (columns 6-10) and non-life insurance penetration (columns 11-15). In Tables 1 and 2, the natural disaster variables are the number of natural disasters, namely epidemic, flood, climatological disasters, earthquake and windstorm that occurred. As can be seen, each natural disaster variable is entered one at a time for each dependent variable in the empirical model. To start, the lagged dependent variable is positive and statistically significant at the 5 per cent level in all equations. These findings indicate that countries that experienced high levels of insurance consumption in the past will continue to experience high insurance consumption in the future.

Consider next the effect of the natural disaster variables on total insurance density (columns 1-5) in Table 1. We find that the natural disaster variables epidemic, flood and windstorm are positive and statistically significant at the 5 per cent level, suggesting that an increase in these natural disaster variables is associated with higher total insurance density. Next, we estimate the GMM model distinguishing between life insurance density and non-life insurance density in our empirical analysis. More specifically, we examine the impact of the natural disaster variables on life insurance density (columns 6-10) and non-life insurance density (columns 11-15) in Table 1. Our results provide evidence that all five natural disaster variables are positive and 
Table 1 GMM regression estimates: Insurance density

\begin{tabular}{|c|c|c|c|c|c|}
\hline & \multicolumn{5}{|c|}{ Total insurance density } \\
\hline & (1) & (2) & (3) & (4) & $(5)$ \\
\hline Lagged dependent variables & $\begin{array}{c}0.559^{* *} \\
(20.437)\end{array}$ & $\begin{array}{c}0.577 * * \\
(13.286)\end{array}$ & $\begin{array}{c}0.543^{* *} \\
(12.718)\end{array}$ & $\begin{array}{c}0.503^{* *} \\
(16.602)\end{array}$ & $\begin{array}{l}0.521 * * \\
(16.910)\end{array}$ \\
\hline Epidemic (number) & $\begin{array}{l}0.020 * * \\
(2.812)\end{array}$ & & & & \\
\hline Flood (number) & & $\begin{array}{l}0.015^{* *} \\
(3.621)\end{array}$ & & & \\
\hline Climatological (number) & & & $\begin{array}{c}0.031 \\
(0.348)\end{array}$ & & \\
\hline Earthquake (number) & & & & $\begin{array}{c}0.013 \\
(1.184)\end{array}$ & \\
\hline Windstorm (number) & & & & & $\begin{array}{l}0.012 * * \\
(4.152)\end{array}$ \\
\hline Real GDP & $\begin{array}{c}0.145 \\
(1.203)\end{array}$ & $\begin{array}{c}0.226 \\
(1.488)\end{array}$ & $\begin{array}{c}0.245^{*} \\
(1.778)\end{array}$ & $\begin{array}{c}0.141 \\
(1.150)\end{array}$ & $\begin{array}{c}0.128 \\
(1.043)\end{array}$ \\
\hline Inflation rate & $\begin{array}{c}-0.021 \\
(-1.315)\end{array}$ & $\begin{array}{l}-0.043^{* *} \\
(-3.233)\end{array}$ & $\begin{array}{c}-0.025^{*} \\
(-1.674)\end{array}$ & $\begin{array}{l}-0.034 * * \\
(-2.374)\end{array}$ & $\begin{array}{c}-0.019 \\
(-1.109)\end{array}$ \\
\hline Interest rate & $\begin{array}{c}-0.016 \\
(-1.116)\end{array}$ & $\begin{array}{c}0.006 \\
(0.288)\end{array}$ & $\begin{array}{c}0.013 \\
(0.657)\end{array}$ & $\begin{array}{c}-0.002 \\
(-0.146)\end{array}$ & $\begin{array}{c}-0.006 \\
(-0.359)\end{array}$ \\
\hline Health expenditure & $\begin{array}{c}0.053 \\
(0.639)\end{array}$ & $\begin{array}{c}-0.012 \\
(-0.075)\end{array}$ & $\begin{array}{c}-0.100 \\
(-0.946)\end{array}$ & $\begin{array}{c}-0.019 \\
(-0.173)\end{array}$ & $\begin{array}{c}-0.047 \\
(-0.427)\end{array}$ \\
\hline Dependency ratio & $\begin{array}{c}-0.381 \\
(-1.624)\end{array}$ & $\begin{array}{c}0.095 \\
(0.152)\end{array}$ & $\begin{array}{l}-0.694 * * \\
(-2.348)\end{array}$ & $\begin{array}{c}-0.456 \\
(-1.645)\end{array}$ & $\begin{array}{c}-0.336 \\
(-1.346)\end{array}$ \\
\hline Arellano-Bond test (1) & 0.032 & 0.002 & 0.001 & 0.002 & 0.021 \\
\hline Arellano-Bond test (2) & 0.221 & 0.223 & 0.378 & 0.100 & 0.145 \\
\hline \multirow[t]{3}{*}{ Hansen test } & 0.115 & 0.110 & 0.110 & 0.111 & 0.114 \\
\hline & \multicolumn{5}{|c|}{ Life insurance density } \\
\hline & (6) & (7) & (8) & (9) & $(10)$ \\
\hline Lagged dependent variables & $\begin{array}{l}0.589 * * \\
(2.468)\end{array}$ & $\begin{array}{l}0.590^{* *} \\
(2.871)\end{array}$ & $\begin{array}{l}0.591 * * \\
(1.116)\end{array}$ & $\begin{array}{l}0.597 * * \\
(1.381)\end{array}$ & $\begin{array}{l}0.592 * * \\
(6.845)\end{array}$ \\
\hline Epidemic (number) & $\begin{array}{c}5.913^{* *} \\
(10.329)\end{array}$ & & & & \\
\hline Flood (number) & & $\begin{array}{l}10.577 * * \\
(24.632)\end{array}$ & & & \\
\hline Climatological (number) & & & $\begin{array}{l}26.789 * * \\
(18.567)\end{array}$ & & \\
\hline Earthquake (number) & & & & $\begin{array}{l}3.511^{* *} \\
(9.657)\end{array}$ & \\
\hline Windstorm (number) & & & & & $\begin{array}{l}10.473 * * \\
(20.129)\end{array}$ \\
\hline Real GDP & $\begin{array}{l}4.630 * * \\
(4.602)\end{array}$ & $\begin{array}{l}2.289 * * \\
(22.386)\end{array}$ & $\begin{array}{l}2.242 * * \\
(8.893)\end{array}$ & $\begin{array}{l}5.744 * * \\
(6.309)\end{array}$ & $\begin{array}{l}6.498 * * \\
(3.700)\end{array}$ \\
\hline Inflation rate & $\begin{array}{l}-8.871^{* *} \\
(-8.208)\end{array}$ & $\begin{array}{l}-9.876 * * \\
(-7.618)\end{array}$ & $\begin{array}{l}-1.556^{* *} \\
(-5.972)\end{array}$ & $\begin{array}{l}-4.568 * * \\
(-9.056)\end{array}$ & $\begin{array}{l}-3.783 * * \\
(-5.055)\end{array}$ \\
\hline Interest rate & $\begin{array}{l}-34.429 * * \\
(-58.809)\end{array}$ & $\begin{array}{l}-38.864^{* *} \\
(-74.649)\end{array}$ & $\begin{array}{l}-46.717 * * \\
(-87.943)\end{array}$ & $\begin{array}{l}-46.754 * * \\
(-96.108)\end{array}$ & $\begin{array}{l}-49.808 * * \\
(-44.959)\end{array}$ \\
\hline
\end{tabular}


Table 1 (continued)

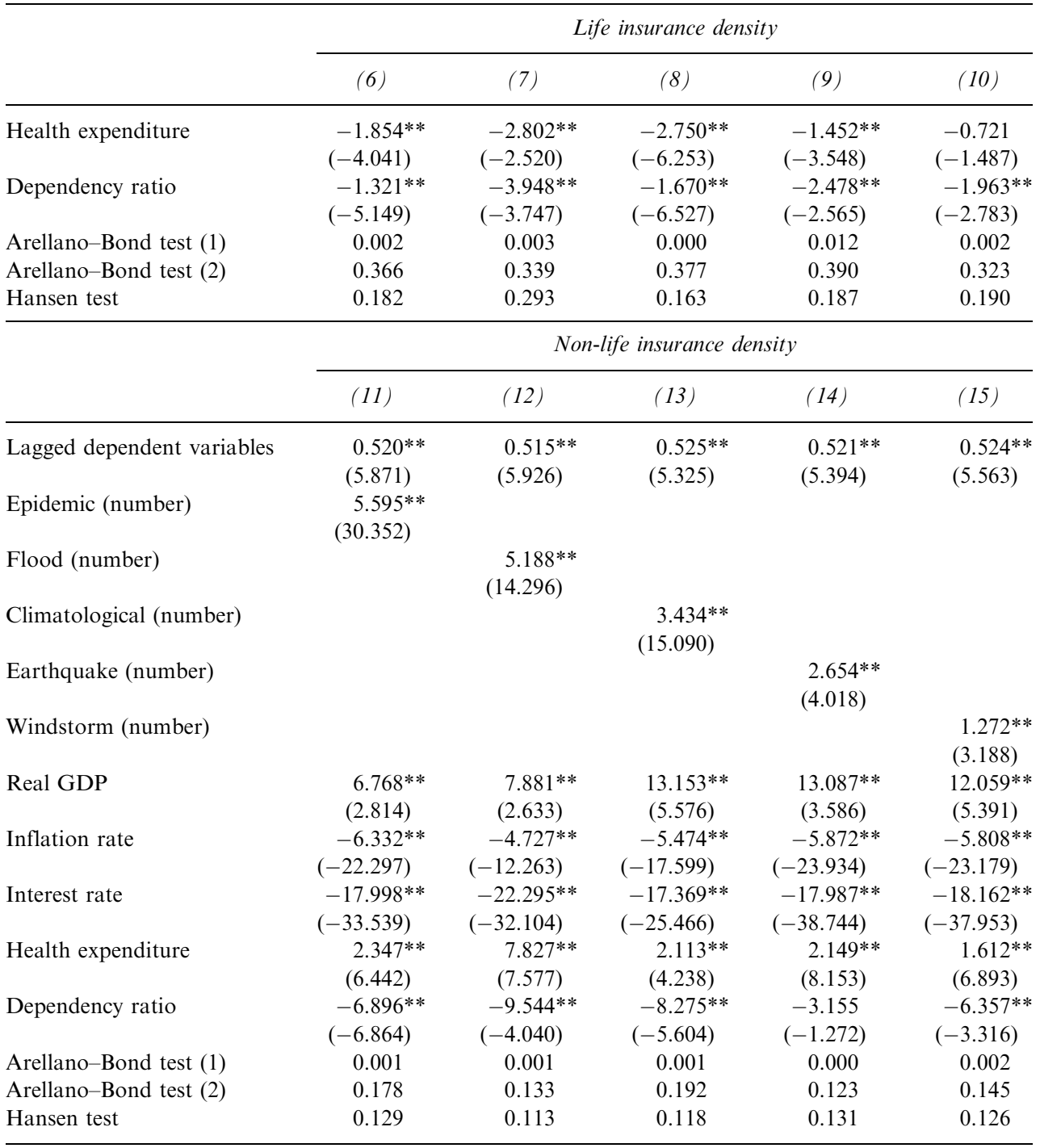

Notes: The natural disaster variables correspond to the incidences (number) of natural disasters that occurred. The regressions include a constant term. The $t$-values are in parentheses. ${ }^{* *}$ and $*$ indicate the statistical significance at the 5 per cent and 10 per cent levels, respectively.

statistically significant at the 5 per cent level in the life insurance and non-life insurance density specifications, indicating that an increase in any of these natural disaster variables contributes to greater life insurance and non-life insurance density.

Furthermore, we analyse the impact of these natural disaster variables on total insurance penetration (columns 1-5) in Table 2. The results suggest that the natural 
Table 2 GMM regression estimates: Insurance penetration

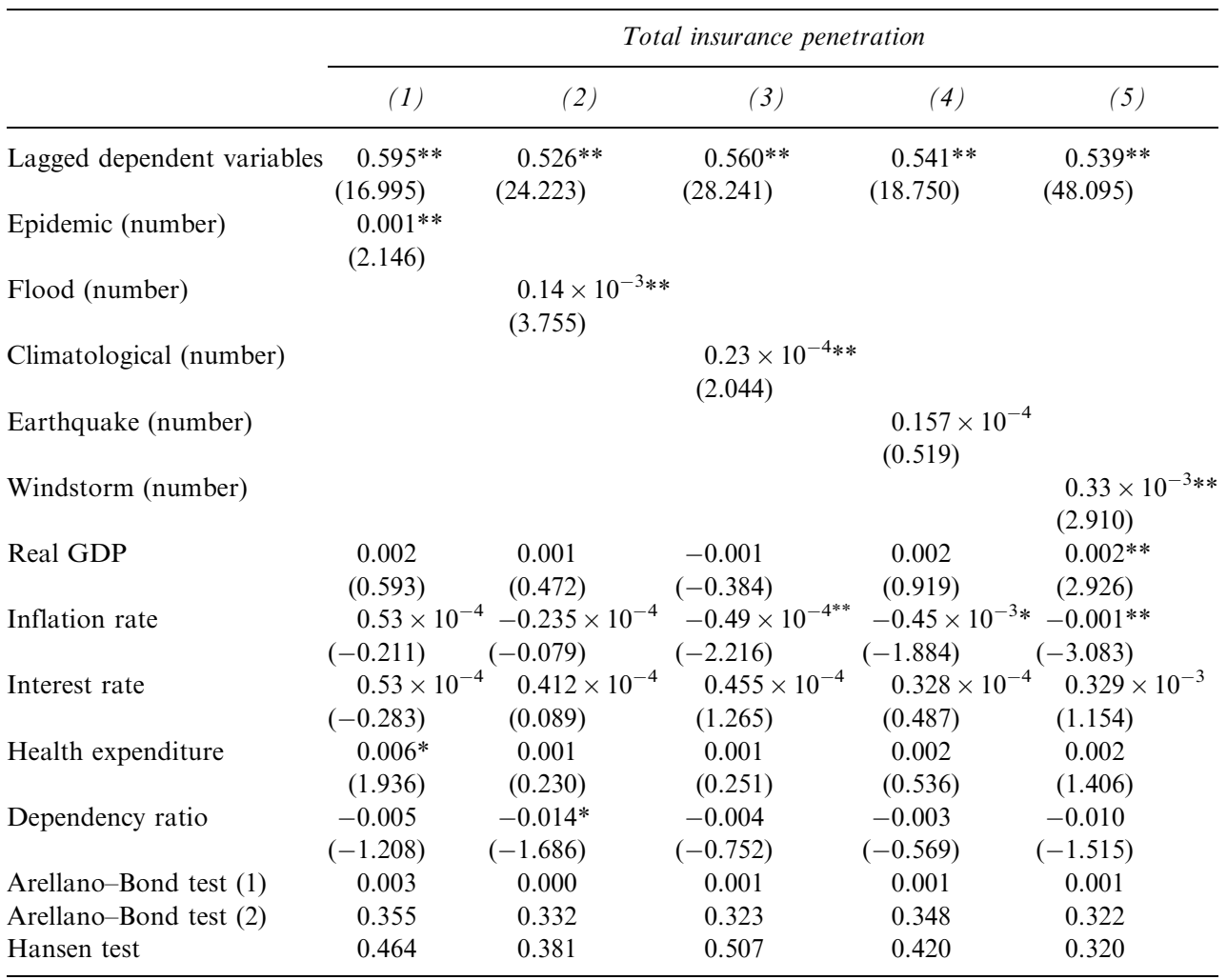

\begin{tabular}{|c|c|c|c|c|c|}
\hline & \multicolumn{5}{|c|}{ Life insurance penetration } \\
\hline & (6) & (7) & (8) & (9) & $(10)$ \\
\hline Lagged dependent variables & $\begin{array}{l}0.561 * * \\
(68.919)\end{array}$ & $\begin{array}{l}0.595^{* *} \\
(99.915)\end{array}$ & $\begin{array}{l}0.591 * * \\
(70.239)\end{array}$ & $\begin{array}{l}0.501^{* *} \\
(81.361)\end{array}$ & $\begin{array}{l}0.505^{* *} \\
(23.142)\end{array}$ \\
\hline Epidemic (number) & $\begin{array}{l}0.46 \times 10^{-3 * *} \\
(2.308)\end{array}$ & & & & \\
\hline Flood (number) & & $\begin{array}{l}0.10 \times 10^{-4 * *} \\
(3.107)\end{array}$ & & & \\
\hline Climatological (number) & & & $\begin{array}{l}0.18 \times 10^{-3 * *} \\
(2.410)\end{array}$ & & \\
\hline Earthquake (number) & & & & $\begin{array}{l}0.11 \times 10^{-3 * *} \\
(4.914)\end{array}$ & \\
\hline Windstorm (number) & & & & & $\begin{array}{l}0.38 \times 10^{-3 *} \\
(1.716)\end{array}$ \\
\hline Real GDP & $\begin{array}{l}-0.001 \\
(-0.761)\end{array}$ & $\begin{array}{l}0.002 * * \\
(3.546)\end{array}$ & $\begin{array}{l}0.002^{* * *} \\
(3.394)\end{array}$ & $\begin{array}{l}0.0028 * \\
(4.137)\end{array}$ & $\begin{array}{l}0.001 * \\
(1.732)\end{array}$ \\
\hline Inflation rate & $\begin{array}{l}-0.063 \times 10^{-4} \\
(-0.435)\end{array}$ & $\begin{array}{l}-0.43 \times 10^{-3^{* *}} \\
(-3.858)\end{array}$ & $\begin{array}{l}-0.001 * * \\
(-3.225)\end{array}$ & $\begin{array}{l}-0.37 \times 10^{-3^{* *}} \\
(-2.952)\end{array}$ & $\begin{array}{l}0.240 \times 10^{-3} \\
(1.283)\end{array}$ \\
\hline Interest rate & $\begin{array}{l}0.268 \times 10^{-3} \\
(0.567)\end{array}$ & $\begin{array}{l}-0.04 \times 10^{-3^{* *}} \\
(-2.603)\end{array}$ & $\begin{array}{l}-0.42 \times 10^{-3^{* *}} \\
(-3.803)\end{array}$ & $\begin{array}{l}-0.26 \times 10^{-3^{* *}} \\
(2.753)\end{array}$ & $\begin{array}{l}-0.93 \times 10^{-4} \\
(-0.383)\end{array}$ \\
\hline
\end{tabular}


Table 2 (continued)

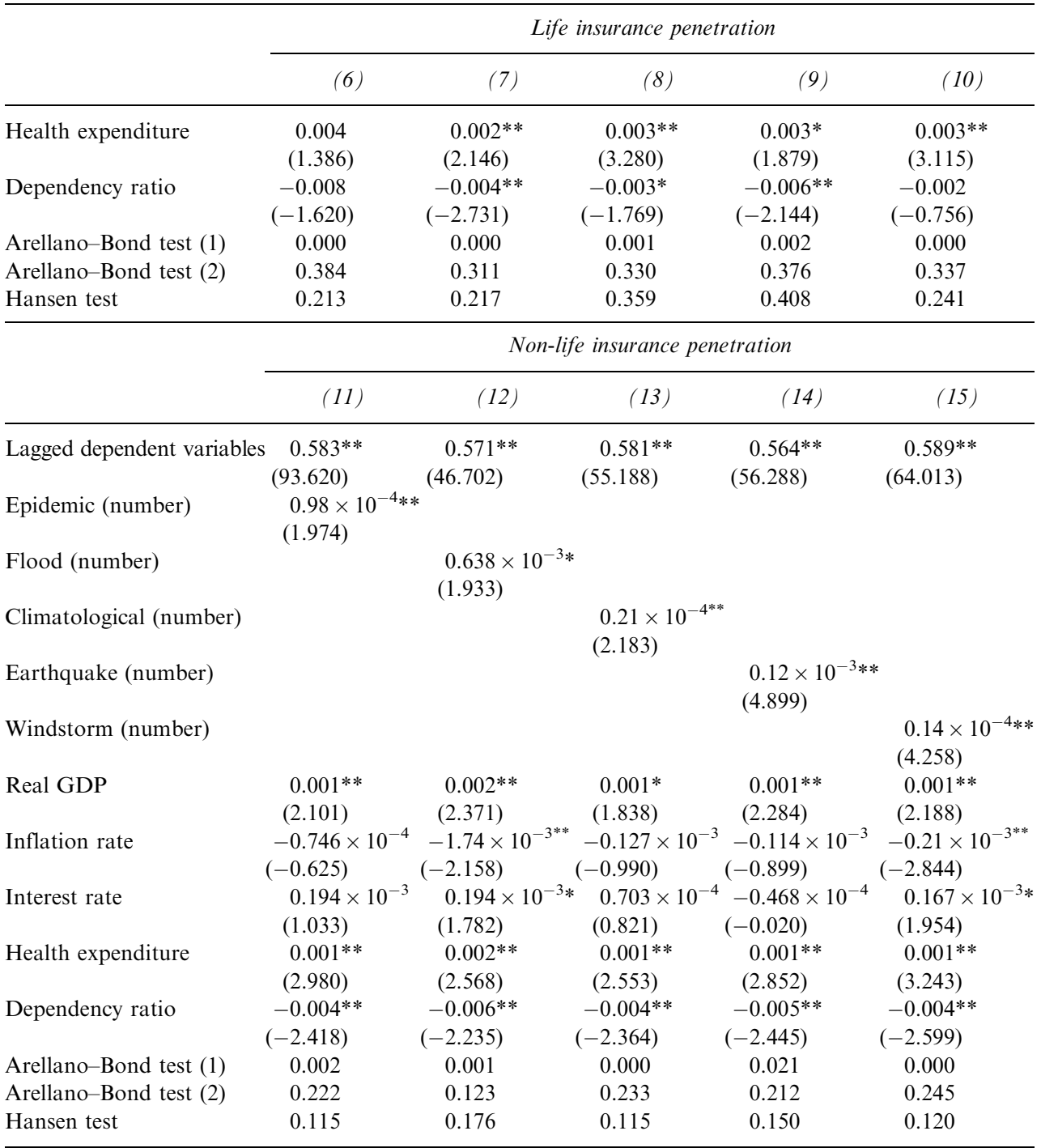

Notes: The natural disaster variables correspond to the incidences (number) of natural disasters that occurred. The regressions include a constant term. The $t$-values are in parentheses. ${ }^{* *}$ and $*$ indicate the statistical significance at the 5 per cent and 10 per cent levels, respectively.

disaster variables epidemic, flood, climatological and windstorm are positive and statistically significant at conventional levels, indicating that an increase in these natural disaster variables leads to higher total insurance penetration. However, it seems that the natural disaster variable earthquake has a limited impact on total insurance penetration, which is evident from the statistically insignificant coefficient 
(column 4) in Table 2. As before, we re-estimate the GMM model, differentiating between life insurance penetration and non-life insurance penetration. We find that a rise in these five natural disaster variables significantly increases life insurance and non-life insurance penetration. Overall, our findings clearly support the notion that the incidence of natural disasters contributes to higher insurance consumption as documented by Kunreuther. ${ }^{5}$

Next, we investigate whether deaths caused by these five natural disaster variables play a role in insurance market development. The GMM regression estimates for the dependent variables total insurance density (columns 1-5), life insurance density (columns 6-10) and non-life insurance density (columns 11-15) are presented in Table 3, whereas the GMM regression estimates for the dependent variables total insurance penetration (columns 1-5), life insurance penetration (columns 6-10) and non-life insurance penetration (columns 11-15) are displayed in Table 4. We find that deaths attributable to epidemic, flood and climatological disasters are associated with higher total insurance density, at least at the 10 per cent level of statistical significance. Moreover, we provide evidence that deaths caused by epidemic, flood, earthquake and climatological disasters significantly contribute to greater life insurance and non-life insurance density.

As before, we examine whether deaths attributable to these five natural disaster variables impact total insurance penetration (columns 1-5) in Table 4. We discover that deaths caused by all five natural disaster variables significantly lead to higher total insurance penetration. These effects are also similar in the non-life insurance penetration model. However, our findings indicate that deaths caused by only epidemic and climatological disasters are associated with higher life insurance penetration. Since natural disasters cause considerable human losses, our results are perhaps surprising, particularly for the life insurance penetration model. This is because life insurance may provide financial protection for the family in the event that a natural disaster causes the untimely death of the primary wage earner. Overall, we provide evidence that deaths attributable to most natural disasters contribute to higher insurance consumption.

We now turn to investigate the impact of the control variables on insurance consumption. The variable real GDP is positive and statistically significant at conventional levels in most equations in Tables $1-4$, indicating that higher national per capita income is associated with insurance market development, including life insurance and non-life insurance. These findings are in line with those of Hammond et al., ${ }^{60}$ Beenstock et al., ${ }^{87}$ Truett and Truett, ${ }^{88}$ Browne and Kim, ${ }^{57}$ Outreville, ${ }^{48}$ Enz, ${ }^{89}$ Ward and Zurbruegg, ${ }^{49}$ Beck and Webb, ${ }^{52}$ Hwang and Greenford, ${ }^{90} \mathrm{Li}$ et al., ${ }^{46}$ and Feyen et al., ${ }^{45}$ who find that an increase in national income leads to greater life insurance consumption. Also, these results are consistent with those of Beenstock et al., ${ }^{91} \mathrm{Enz}^{89}$, Browne et al., ${ }^{44}$ Esho et al. ${ }^{63}$ and Feyen et al., ${ }^{45}$

\footnotetext{
${ }^{87}$ Beenstock et al. (1986).

${ }^{88}$ Truett and Truett (1990).

${ }^{89}$ Enz (2000).

${ }^{90}$ Hwang and Greenford (2005).

${ }^{91}$ Beenstock et al. (1988).
} 
Table 3 GMM regression estimates: Insurance density

\begin{tabular}{|c|c|c|c|c|c|}
\hline & \multicolumn{5}{|c|}{ Total insurance density } \\
\hline & (1) & (2) & (3) & (4) & (5) \\
\hline Lagged dependent variables & $\begin{array}{l}0.654 * * \\
(8.959)\end{array}$ & $\begin{array}{l}0.664 * * \\
(4.794)\end{array}$ & $\begin{array}{l}0.667 * * \\
(4.445)\end{array}$ & $\begin{array}{c}0.665^{* *} \\
(7.365)\end{array}$ & $\begin{array}{l}0.666^{* *} \\
(5.773)\end{array}$ \\
\hline Epidemic (death) & $\begin{array}{l}0.779 \times 10^{-4 *} \\
(1.755)\end{array}$ & & & & \\
\hline Flood (death) & & $\begin{array}{l}0.473 \times 10^{-5 * *} \\
(4.078)\end{array}$ & & & \\
\hline Climatological (death) & & & $\begin{array}{l}0.143 \times 10^{-4 *} \\
(2.453)\end{array}$ & & \\
\hline Earthquake (death) & & & & $\begin{array}{l}0.229 \times 10^{-6} \\
(0.824)\end{array}$ & \\
\hline Windstorm (death) & & & & & $\begin{array}{l}-0.296 \times 10^{-5} \\
(0.377)\end{array}$ \\
\hline Real GDP & $\begin{array}{c}0.082 \\
(1.013)\end{array}$ & $\begin{array}{c}0.023 \\
(0.409)\end{array}$ & $\begin{array}{c}0.038 \\
(0.657)\end{array}$ & $\begin{array}{c}0.010 \\
(0.186)\end{array}$ & $\begin{array}{c}0.032 \\
(0.497)\end{array}$ \\
\hline Inflation rate & $\begin{array}{l}-0.036^{* *} \\
(-3.344)\end{array}$ & $\begin{array}{l}-0.036^{* *} \\
(-2.584)\end{array}$ & $\begin{array}{l}-0.037 * * \\
(-3.116)\end{array}$ & $\begin{array}{l}-0.039 * * \\
(-2.989)\end{array}$ & $\begin{array}{l}-0.039 * * \\
(-3.591)\end{array}$ \\
\hline Interest rate & $\begin{array}{l}-0.037 * * \\
(-2.885)\end{array}$ & $\begin{array}{l}-0.038 * * \\
(-3.233)\end{array}$ & $\begin{array}{l}-0.036^{* *} \\
(-3.251)\end{array}$ & $\begin{array}{l}-0.040 * * \\
(-3.131)\end{array}$ & $\begin{array}{l}-0.040 * * \\
(-3.274)\end{array}$ \\
\hline Health expenditure & $\begin{array}{c}-0.013 \\
(-0.187)\end{array}$ & $\begin{array}{c}0.077 \\
(0.844)\end{array}$ & $\begin{array}{c}0.029 \\
(0.489)\end{array}$ & $\begin{array}{c}0.098 \\
(1.099)\end{array}$ & $\begin{array}{c}0.055 \\
(0.978)\end{array}$ \\
\hline Dependency ratio & $\begin{array}{c}-0.112 \\
(-0.695)\end{array}$ & $\begin{array}{c}-0.059 \\
(-0.398)\end{array}$ & $\begin{array}{c}-0.148 \\
(-0.883)\end{array}$ & $\begin{array}{c}-0.045 \\
(-0.315)\end{array}$ & $\begin{array}{c}-0.090 \\
(-0.681)\end{array}$ \\
\hline Arellano-Bond test (1) & 0.000 & 0.001 & 0.000 & 0.001 & 0.000 \\
\hline Arellano-Bond test (2) & 0.116 & 0.211 & 0.223 & 0.135 & 0.222 \\
\hline Hansen test & 0.223 & 0.214 & 0.329 & 0.323 & 0.310 \\
\hline
\end{tabular}

\begin{tabular}{|c|c|c|c|c|c|}
\hline & \multicolumn{5}{|c|}{ Life insurance density } \\
\hline & (6) & (7) & $(8)$ & (9) & $(10)$ \\
\hline Lagged dependent variables & $\begin{array}{l}0.694^{* *} \\
(6.587)\end{array}$ & $\begin{array}{l}0.654^{* * *} \\
(8.218)\end{array}$ & $\begin{array}{l}0.695^{* *} \\
(7.807)\end{array}$ & $\begin{array}{l}0.655^{* *} \\
(8.482)\end{array}$ & $\begin{array}{l}0.695 * * \\
(6.492)\end{array}$ \\
\hline Epidemic (death) & $\begin{array}{l}0.062 * * \\
(6.685)\end{array}$ & & & & \\
\hline Flood (death) & & $\begin{array}{c}0.003 * * \\
(19.851)\end{array}$ & & & \\
\hline Climatological (death) & & & $\begin{array}{c}0.010^{* *} \\
(16.553)\end{array}$ & & \\
\hline Earthquake (death) & & & & $\begin{array}{l}0.035^{* *} \\
(5.885)\end{array}$ & \\
\hline Windstorm (death) & & & & & $\begin{array}{l}0.346 \times 10^{-3} \\
(0.141)\end{array}$ \\
\hline Real GDP & $\begin{array}{c}6.399 * * \\
(14.063)\end{array}$ & $\begin{array}{l}2.691 * * \\
(3.011)\end{array}$ & $\begin{array}{c}6.816^{* *} \\
(32.565)\end{array}$ & $\begin{array}{c}9.046^{* *} \\
(16.107)\end{array}$ & $\begin{array}{l}6.422 * * \\
(11.863)\end{array}$ \\
\hline Inflation rate & $\begin{array}{c}-4.337 * * \\
(-12.149)\end{array}$ & $\begin{array}{l}-11.377 * * \\
(-24.466)\end{array}$ & $\begin{array}{c}-3.482^{* *} \\
(-13.842)\end{array}$ & $\begin{array}{l}-10.128 * * \\
(-27.109)\end{array}$ & $\begin{array}{l}-2.489 * * \\
(-3.527)\end{array}$ \\
\hline Interest rate & $\begin{array}{l}-46.120 * * \\
(-15.965)\end{array}$ & $\begin{array}{l}-44.520 * * \\
(-74.399)\end{array}$ & $\begin{array}{l}-44.098 * * \\
(-44.098)\end{array}$ & $\begin{array}{l}-46.820 \\
(-1.080)\end{array}$ & $\begin{array}{c}-4.756 \\
(-1.070)\end{array}$ \\
\hline
\end{tabular}


Table 3 (continued)

\begin{tabular}{|c|c|c|c|c|c|}
\hline & \multicolumn{5}{|c|}{ Life insurance density } \\
\hline & (6) & (7) & (8) & (9) & $(10)$ \\
\hline Health expenditure & $\begin{array}{l}26.437 * * \\
(8.062)\end{array}$ & $\begin{array}{l}89.644 * * \\
(8.390)\end{array}$ & $\begin{array}{l}27.484^{* *} \\
(6.153)\end{array}$ & $\begin{array}{l}45.773 * * \\
(24.735)\end{array}$ & $\begin{array}{l}25.396^{* * *} \\
(3.733)\end{array}$ \\
\hline Dependency ratio & $\begin{array}{l}-1.758^{* *} \\
(-8.613)\end{array}$ & $\begin{array}{l}-8.482 * * \\
(-9.854)\end{array}$ & $\begin{array}{l}-1.714^{* *} \\
(-2.078)\end{array}$ & $\begin{array}{l}-0.874 * * \\
(-5.234)\end{array}$ & $\begin{array}{l}-1.872 * * \\
(-3.054)\end{array}$ \\
\hline Arellano-Bond test (1) & 0.001 & 0.001 & 0.001 & 0.001 & 0.001 \\
\hline Arellano-Bond test (2) & 0.323 & 0.323 & 0.333 & 0.323 & 0.332 \\
\hline \multirow[t]{3}{*}{ Hansen test } & 0.165 & 0.284 & 0.245 & 0.224 & 0.162 \\
\hline & \multicolumn{5}{|c|}{ Non-life insurance density } \\
\hline & (11) & (12) & (13) & (14) & $(15)$ \\
\hline Lagged dependent variables & $\begin{array}{l}0.618 * * \\
(9.843)\end{array}$ & $\begin{array}{l}0.618^{* *} \\
(9.162)\end{array}$ & $\begin{array}{l}0.619 * * \\
(7.649)\end{array}$ & $\begin{array}{l}0.619 * * \\
(3.346)\end{array}$ & $\begin{array}{l}0.617 * * \\
(5.637)\end{array}$ \\
\hline Epidemic (death) & $\begin{array}{c}0.013^{*} \\
(1.870)\end{array}$ & & & & \\
\hline Flood (death) & & $\begin{array}{c}0.001 * * \\
(10.935)\end{array}$ & & & \\
\hline Climatological (death) & & & $\begin{array}{c}0.007 * * \\
(46.958)\end{array}$ & & \\
\hline Earthquake (death) & & & & $\begin{array}{l}0.001 * * \\
(3.240)\end{array}$ & \\
\hline Windstorm (death) & & & & & $\begin{array}{c}0.002 \\
(0.522)\end{array}$ \\
\hline Real GDP & $\begin{array}{l}4.716^{* *} \\
(4.482)\end{array}$ & $\begin{array}{l}3.027 * * \\
(2.187)\end{array}$ & $\begin{array}{l}5.014 * * \\
(2.180)\end{array}$ & $\begin{array}{l}5.660 * * \\
(3.011)\end{array}$ & $\begin{array}{c}-1.861 \\
(-0.832)\end{array}$ \\
\hline Inflation rate & $\begin{array}{c}-8.422^{* *} \\
(-42.908)\end{array}$ & $\begin{array}{c}-8.115^{* *} \\
(-32.313)\end{array}$ & $\begin{array}{c}-8.427 * * \\
(-28.953)\end{array}$ & $\begin{array}{c}-8.488 * * \\
(-63.990)\end{array}$ & $\begin{array}{l}-8.502^{* *} \\
(-26.200)\end{array}$ \\
\hline Interest rate & $\begin{array}{l}-21.229 * * \\
(-56.320)\end{array}$ & $\begin{array}{l}-21.359 * * \\
(-11.049)\end{array}$ & $\begin{array}{l}-20.450 * * \\
(-42.569)\end{array}$ & $\begin{array}{l}-20.757 * * \\
(-49.431)\end{array}$ & $\begin{array}{l}-21.430 * * \\
(-33.608)\end{array}$ \\
\hline Health expenditure & $\begin{array}{c}4.263 \\
(1.015)\end{array}$ & $\begin{array}{l}10.793^{*} \\
(1.806)\end{array}$ & $\begin{array}{l}8.546^{* *} \\
(6.178)\end{array}$ & $\begin{array}{c}9.468 * * \\
(9.610)\end{array}$ & $\begin{array}{c}8.534 * * \\
(8.239)\end{array}$ \\
\hline Dependency ratio & $\begin{array}{c}-2.977 \\
(-0.570)\end{array}$ & $\begin{array}{c}-4.067 \\
(-1.486)\end{array}$ & $\begin{array}{c}-1.667 \\
(-0.303)\end{array}$ & $\begin{array}{c}-3.693 \\
(-1.636)\end{array}$ & $\begin{array}{l}-2.414 \\
(-0.679)\end{array}$ \\
\hline Arellano-Bond test (1) & 0.002 & 0.002 & 0.003 & 0.000 & 0.001 \\
\hline Arellano-Bond test (2) & 0.211 & 0.199 & 0.189 & 0.119 & 0.199 \\
\hline Hansen test & 0.257 & 0.238 & 0.263 & 0.217 & 0.221 \\
\hline
\end{tabular}

Notes: The natural disaster variables correspond to deaths caused by natural disasters. The regressions include a constant term. The $t$-values are in parentheses. ${ }^{* *}$ and $*$ indicate the statistical significance at the 5 per cent and 10 per cent levels, respectively. 
Table 4 GMM regression estimates: Insurance penetration

\begin{tabular}{|c|c|c|c|c|c|}
\hline & \multicolumn{5}{|c|}{ Total insurance penetration } \\
\hline & (1) & (2) & (3) & (4) & $(5)$ \\
\hline Lagged dependent & $0.586^{* *}$ & $0.563 * *$ & $0.581 * *$ & $0.544 * *$ & $0.565^{* *}$ \\
\hline & $(4.632)$ & $(4.412)$ & $(9.003)$ & $(3.120)$ & $(3.945)$ \\
\hline Epidemic (death) & $\begin{array}{l}0.33 \times 10^{-5 * *} \\
(2.185)\end{array}$ & & & & \\
\hline Flood (death) & \multirow{2}{*}{\multicolumn{2}{|c|}{$\begin{aligned} & 0.12 \times 10^{-6 * *} \\
& (5.314)\end{aligned}$}} & & & \\
\hline Climatological (death) & & & $\begin{array}{l}0.17 \times 10^{-6 *} \\
(1.707)\end{array}$ & & \\
\hline Earthquake (death) & & & & $\begin{array}{l}0.312 \times 10^{-9 * *} \\
(4.008)\end{array}$ & \\
\hline Windstorm (death) & & & & & $\begin{array}{l}0.11 \times 10^{-5^{* *}} \\
(2.204)\end{array}$ \\
\hline Real GDP & $\begin{array}{c}0.002 \\
(1.247)\end{array}$ & $\begin{array}{l}0.003 * \\
(1.923)\end{array}$ & $\begin{array}{c}0.003 \\
(1.551)\end{array}$ & $\begin{array}{l}0.004^{*} \\
(1.865)\end{array}$ & $\begin{array}{c}0.003 \\
(1.430)\end{array}$ \\
\hline Inflation rate & $\begin{array}{l}-0.001 * * \\
(-4.806)\end{array}$ & $\begin{array}{l}-0.48 \times 10^{-3 *} \\
(-1.776)\end{array}$ & $\begin{array}{l}-0.001 * * \\
(-2.520)\end{array}$ & $\begin{array}{l}0.382 \times 10^{-3} \\
(1.134)\end{array}$ & $\begin{array}{l}-0.001 * * \\
(-3.290)\end{array}$ \\
\hline Interest rate & $\begin{array}{l}-0.210 \times 10^{-4} \\
(-0.103)\end{array}$ & $\begin{array}{l}-0.119 \times 10^{-3} \\
(-0.543)\end{array}$ & $\begin{array}{l}0.211 \times 10^{-3} \\
(0.619)\end{array}$ & $\begin{array}{l}-0.15 \times 10^{-3} \\
(-0.568)\end{array}$ & $\begin{array}{l}-0.14 \times 10^{-4} \\
(-0.081)\end{array}$ \\
\hline Health expenditure & $\begin{array}{l}-0.003^{*} \\
(-1.739)\end{array}$ & $\begin{array}{l}-0.003^{*} \\
(-1.794)\end{array}$ & $\begin{array}{l}-0.005 * * \\
(-2.288)\end{array}$ & $\begin{array}{c}-0.003 \\
(-1.478)\end{array}$ & $\begin{array}{c}-0.003 \\
(-1.628)\end{array}$ \\
\hline Dependency ratio & $\begin{array}{c}0.003 \\
(0.659)\end{array}$ & $\begin{array}{l}-0.003 \\
(-0.565)\end{array}$ & $\begin{array}{l}0.131 \times 10^{-4} \\
(0.002)\end{array}$ & $\begin{array}{c}0.004 \\
(0.895)\end{array}$ & $\begin{array}{l}-0.001 \\
(-0.125)\end{array}$ \\
\hline Arellano-Bond test (1) & 0.000 & 0.001 & 0.001 & 0.000 & 0.002 \\
\hline Arellano-Bond test (2) & 0.209 & 0.503 & 0.543 & 0.458 & 0.432 \\
\hline Hansen test & 0.375 & 0.531 & 0.377 & 0.503 & 0.583 \\
\hline
\end{tabular}

\begin{tabular}{|c|c|c|c|c|c|}
\hline & \multicolumn{5}{|c|}{ Life insurance penetration } \\
\hline & (6) & (7) & (8) & (9) & (10) \\
\hline Lagged dependent variables & $\begin{array}{l}0.503 * * \\
(2.237)\end{array}$ & $\begin{array}{l}0.503 * * \\
(9.303)\end{array}$ & $\begin{array}{l}0.554 * * \\
(7.007)\end{array}$ & $\begin{array}{l}0.559^{* *} \\
(4.946)\end{array}$ & $\begin{array}{l}0.503 * * \\
(4.486)\end{array}$ \\
\hline Epidemic (death) & $\begin{array}{l}0.943 \times 10^{-6 * *} \\
(5.612)\end{array}$ & & & & \\
\hline Flood (death) & & $\begin{array}{l}-0.920 \times 10^{-7} \\
(0.925)\end{array}$ & & & \\
\hline Climatological (death) & & & $\begin{array}{l}0.133 \times 10^{-6 * *} \\
(4.220)\end{array}$ & & \\
\hline Earthquake (death) & & & & $\begin{array}{l}0.19 \times 10^{-7} \\
(1.617)\end{array}$ & \\
\hline Windstorm (death) & & & & & $\begin{array}{l}0.43 \times 10^{-6} \\
(0.624)\end{array}$ \\
\hline Real GDP & $\begin{array}{l}0.001 * * \\
(2.197)\end{array}$ & $\begin{array}{l}0.002 * * \\
(2.078)\end{array}$ & $\begin{array}{l}0.002 * * \\
(3.045)\end{array}$ & $\begin{array}{c}0.002 * \\
(1.827)\end{array}$ & $\begin{array}{c}0.002 \\
(1.361)\end{array}$ \\
\hline Inflation rate & $\begin{array}{l}-0.49 \times 10^{-3 * *} \\
(-4.129)\end{array}$ & $\begin{array}{l}-0.001^{* *} \\
(-4.535)\end{array}$ & $\begin{array}{l}-0.46 \times 10-3 * * \\
(-2.283)\end{array}$ & $\begin{array}{l}0.22 \times 10^{-3} \\
(0.890)\end{array}$ & $\begin{array}{l}-0.001 * * \\
(-3.044)\end{array}$ \\
\hline Interest rate & $-0.863 \times 10^{-4}$ & $-0.37 \times 10^{-3 * *}$ & $*-0.38 \times 10^{-3 * *}$ & $-0.001 * *$ & $-0.001 * *$ \\
\hline
\end{tabular}


Table 4 (continued)

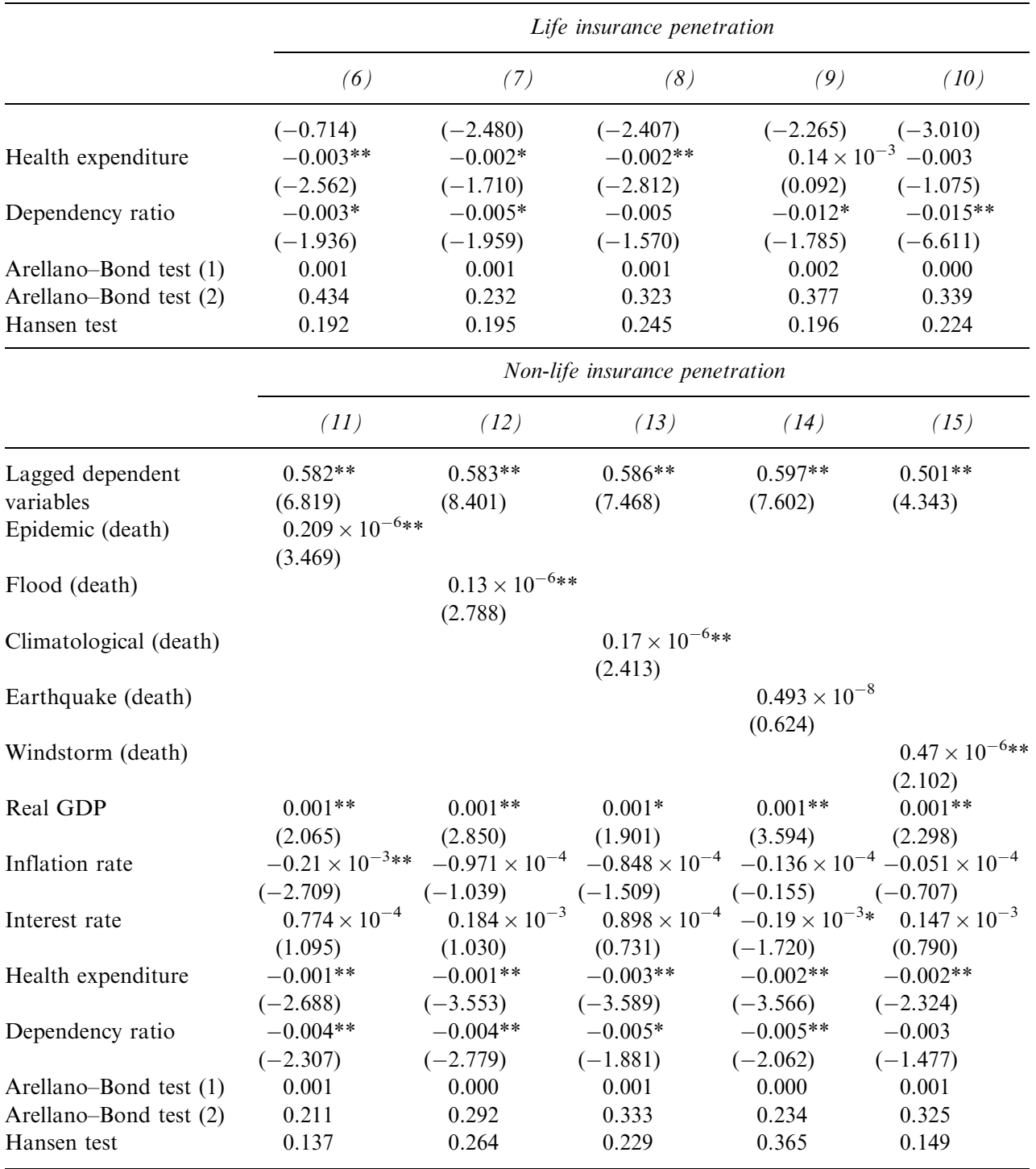

Notes: The natural disaster variables correspond to deaths caused by natural disasters. The regressions include a constant term. The $t$-values are in parentheses. $* *$ and $*$ indicate the statistical significance at the 5 per cent and 10 per cent levels, respectively.

who show that aggregate income contributes to higher non-life insurance consumption.

As anticipated, we find that the variable inflation rate is negative and statistically significant in most specifications at least at the 10 per cent level, suggesting that higher rates of inflation reduce total insurance consumption, as well as life insurance and non-life insurance consumption. These findings are in line with Browne and Kim, ${ }^{57}$ 
Outreville, ${ }^{48}$ Ward and Zurbruegg, ${ }^{49}$ Beck and Webb, ${ }^{52}$ Li et al. ${ }^{46}$ and Feyen et al.,${ }^{45}$ who discover that a rise in the inflation rate lowers life insurance consumption. Overall, our results also indicate that higher interest rates contribute to a decrease in life insurance and non-life insurance consumption. These findings are in line with Li et al. ${ }^{46}$ who find that greater interest rates are associated with lower life insurance consumption. However, these results are not consistent with Beck and Webb, ${ }^{52}$ who show that countries with higher interest rates experience life insurance market development. ${ }^{92}$

In general, our results provide mixed findings on the relationship between health expenditures and insurance market development. In Table 1, for example, we find evidence that higher health expenditures are associated with lower life insurance density (columns 6-10), while higher health expenditures contribute to greater non-life insurance density (columns 11-15). Furthermore, this effect is statistically insignificant at conventional levels in the total insurance density model (columns 1-5) in Table 1. In addition, our findings overall suggest that higher health expenditures are associated with higher insurance penetration in Table 2. Nevertheless, we provide evidence that the variable health expenditure is positive and statistically significant at conventional levels in Tables 3 and 4. Overall, we find no robust relationship between government health expenditures and total insurance market development, including life insurance and non-life insurance consumption.

The literature also finds that the relationship between government expenditures on social welfare and insurance market development is rather uncertain. Browne and $\mathrm{Kim}^{57}$ find that government spending on social welfare leads to higher life insurance consumption. However, Beenstock et al. ${ }^{87}$ Ward and Zurbruegg, ${ }^{49} \mathrm{Li}$ et al. ${ }^{46}$ and Feyen et $a l .{ }^{45}$ show that higher government provisions on social welfare reduce life insurance consumption. Furthermore, Outreville, ${ }^{48}$ Beck and Webb, ${ }^{52}$ and Hwang and Greenford ${ }^{90}$ discover that public provision on social welfare has a statistically insignificant impact on life insurance market development. Since these studies generally employ different measures of government spending on social welfare and often utilise diverse sets of countries in the empirical analysis, it is perhaps not surprising that the literature finds no robust link between public expenditures on social welfare and insurance consumption. ${ }^{45}$

Finally, the variable dependency ratio has a statistically insignificant impact on total insurance consumption in most equations in Tables 1-4. Alternatively, this effect is negative and statistically significant at least at the 10 per cent level in most equations for the life insurance and non-insurance models in Tables $1-4$, thereby providing evidence that a higher dependency ratio causes a decline in insurance consumption. These results are not consistent with the theoretical work of Campbel1 ${ }^{93}$ and the empirical works of Hammond et al. ${ }^{60}$ Beenstock et al. ${ }^{87}$ Truett and Truett, ${ }^{88}$ Browne and Kim, ${ }^{57}$ Hwang and Greenford, ${ }^{90}$ Li et al.,${ }^{46}$ and Feyen et al. ${ }^{45}$ who show that a

\footnotetext{
${ }^{92}$ As can be seen, we also find evidence that higher interest rates have a statistically insignificant influence on insurance market development. It is also important to note that Outreville (1996) finds interest rates have a statistically insignificant impact on life insurance market development.

${ }^{93}$ Campbell (1980).
} 
greater dependency ratio is associated with higher life insurance market development. ${ }^{94}$ Nevertheless, our results are in line with those of Ward and Zurbruegg, ${ }^{49}$ who discover that an increase in the young dependency ratio contributes to lower life insurance consumption in a sample of 16 Asian countries. ${ }^{95}$

We provide the results of Hansen and Arellano-Bond tests at the bottom of each table. The Hansen test of over-identification restrictions tests the validity of the instruments (amounting to a test for the exogeneity of the covariates). As can be seen, the Hansen test cannot reject the null hypothesis (p-value $>0.10$ ) in all equations, suggesting that the instrumental variables are valid in the estimation. Next, the Arellano-Bond tests of first-order autocorrelation and second-order autocorrelation tests that the estimated residuals do not produce first-order and second-order serial correlation, respectively. While autocorrelation of the first-order prevails by definition, second-order autocorrelation must be absent in order for the estimator to be consistent. The Arellano-Bond test of second-order autocorrelation cannot reject the null hypothesis ( $\mathrm{p}$-value $>0.10$ ) in all equations, indicating that the estimated residuals do not produce second-order serial correlation and, thus, the estimators are consistent in all specifications.

\section{Extended specification}

In the extended model, we estimate whether the political risk level of a country impacts insurance market development. In addition, we examine the interaction effects of natural disaster variables and the political risk level of a country on insurance consumption. We provide the regression estimates for the dependent variables' total insurance density (columns 1-5), life insurance density (columns 6-10) and non-life insurance density (columns 11-15) in Table 5, whereas the regression estimates for the dependent variables' total insurance penetration (columns 1-5), life insurance penetration (columns 6-10) and non-life insurance penetration (columns 11-15) are presented in Table 6. In Tables 5 and 6, the natural disaster variables are the number of natural disasters, specifically epidemic, flood, climatological disasters, earthquake and windstorm that occurred. As before, we employ a two-step system GMM model in the empirical analysis.

To start, we find that epidemic, flood, windstorm and climatological disasters are associated with higher total insurance density at least at the 10 per cent level of statistical significance in Table 5. Also, it appears that all five natural disaster variables contribute to larger life insurance density, at the 5 per cent level of statistical significance. These effects are also similar in the non-life insurance density model, except for the natural disaster variable flood (column 12) in Table 5, which is statistically insignificant at conventional levels. Also, we find that the natural disaster variables epidemic, flood, climatological disasters and windstorm are significantly

\footnotetext{
${ }^{94}$ Moreover, Outreville (1996), and Beck and Webb (2003) find that the young dependency ratio has a statistically insignificant impact on life insurance consumption. However, Beck and Webb (2003) also show that a rise in the old dependency ratio leads to higher life insurance consumption.

${ }^{95}$ It is important to note that Ward and Zurbruegg (2002) also find that higher young dependency ratio is associated with higher life insurance consumption in a sample of 25 OECD countries.
} 
Table 5 GMM regression estimates: Insurance density

\begin{tabular}{|c|c|c|c|c|c|}
\hline & & & insurance $d$ & & \\
\hline & (1) & (2) & (3) & (4) & $(5)$ \\
\hline Lagged dependent variables & $\begin{array}{l}0.559 * * \\
(6.287)\end{array}$ & $\begin{array}{l}0.555^{* *} \\
(3.469)\end{array}$ & $\begin{array}{l}0.514^{* *} \\
(2.990)\end{array}$ & $\begin{array}{l}0.561 * * \\
(3.657)\end{array}$ & $\begin{array}{l}0.527 * * \\
(2.917)\end{array}$ \\
\hline Epidemic (number) & $\begin{array}{l}0.160^{* *} \\
(4.693)\end{array}$ & & & & \\
\hline Flood (number) & & $\begin{array}{c}0.191^{*} \\
(1.832)\end{array}$ & & & \\
\hline Climatological (number) & & & $\begin{array}{l}1.085^{* *} \\
(2.402)\end{array}$ & & \\
\hline Earthquake (number) & & & & $\begin{array}{c}0.160 \\
(0.458)\end{array}$ & \\
\hline Windstorm (number) & & & & & $\begin{array}{l}0.122 * * \\
(2.480)\end{array}$ \\
\hline Risk & $\begin{array}{c}0.108 \\
(0.978)\end{array}$ & $\begin{array}{l}0.294^{* *} \\
(2.553)\end{array}$ & $\begin{array}{l}0.177 * * \\
(3.100)\end{array}$ & $\begin{array}{l}0.016^{* * *} \\
(2.115)\end{array}$ & $\begin{array}{c}0.165 \\
(0.990)\end{array}$ \\
\hline Epidemic $\times$ risk & $\begin{array}{l}0.042^{* *} \\
(2.759)\end{array}$ & & & & \\
\hline Flood $\times$ risk & & $\begin{array}{c}0.043^{*} \\
(1.698)\end{array}$ & & & \\
\hline Climatological $\times$ risk & & & $\begin{array}{l}0.257 * * \\
(2.480)\end{array}$ & & \\
\hline Earthquake $\times$ risk & & & & $\begin{array}{c}0.037 * * \\
(3.439)\end{array}$ & \\
\hline Windstorm $\times$ risk & & & & & $\begin{array}{l}0.032 * * \\
(2.543)\end{array}$ \\
\hline Real GDP & $\begin{array}{c}0.022 \\
(0.473)\end{array}$ & $\begin{array}{c}0.052 \\
(0.588)\end{array}$ & $\begin{array}{c}0.140^{*} \\
(1.756)\end{array}$ & $\begin{array}{c}0.045 \\
(0.631)\end{array}$ & $\begin{array}{c}0.091 \\
(1.271)\end{array}$ \\
\hline Inflation rate & $\begin{array}{l}-0.043^{* *} \\
(-4.576)\end{array}$ & $\begin{array}{l}-0.043 * * \\
(-2.581)\end{array}$ & $\begin{array}{l}-0.036^{* *} \\
(-2.781)\end{array}$ & $\begin{array}{l}-0.044 * * \\
(-3.463)\end{array}$ & $\begin{array}{l}-0.040^{* *} \\
(-3.227)\end{array}$ \\
\hline Interest rate & $\begin{array}{l}-0.031 * * \\
(-3.162)\end{array}$ & $\begin{array}{l}-0.028 * * \\
(-1.976)\end{array}$ & $\begin{array}{l}-0.035^{* *} \\
(-1.960)\end{array}$ & $\begin{array}{l}-0.036^{* *} \\
(-2.947)\end{array}$ & $\begin{array}{l}-0.029 * * \\
(-2.069)\end{array}$ \\
\hline Health expenditure & $\begin{array}{c}0.072 \\
(0.978)\end{array}$ & $\begin{array}{c}0.022 \\
(0.150)\end{array}$ & $\begin{array}{c}0.056 \\
(0.718)\end{array}$ & $\begin{array}{c}0.017 \\
(0.191)\end{array}$ & $\begin{array}{c}0.053 \\
(0.630)\end{array}$ \\
\hline Dependency ratio & $\begin{array}{c}-0.093 \\
(-0.520)\end{array}$ & $\begin{array}{c}-0.102 \\
(-0.453)\end{array}$ & $\begin{array}{c}-0.140 \\
(-0.798)\end{array}$ & $\begin{array}{c}-0.026 \\
(-0.136)\end{array}$ & $\begin{array}{c}-0.118 \\
(-0.436)\end{array}$ \\
\hline Arellano-Bond test (1) & 0.001 & 0.001 & 0.000 & 0.000 & 0.001 \\
\hline Arellano-Bond test (2) & 0.211 & 0.220 & 0.434 & 0.322 & 0.213 \\
\hline Hansen test & 0.113 & 0.150 & 0.104 & 0.107 & 0.108 \\
\hline & & & insurance de & & \\
\hline & (6) & (7) & (8) & (9) & (10) \\
\hline Lagged dependent variables & $\begin{array}{l}0.551^{* *} \\
(7.264)\end{array}$ & $\begin{array}{l}0.542^{* *} \\
(3.363)\end{array}$ & $\begin{array}{l}0.549 * * \\
(5.872)\end{array}$ & $\begin{array}{l}0.551 * * \\
(4.349)\end{array}$ & $\begin{array}{l}0.550 * * \\
(6.940)\end{array}$ \\
\hline Epidemic (number) & $\begin{array}{c}1.499 * * \\
(48.590)\end{array}$ & & & & \\
\hline Flood (number) & & $\begin{array}{c}1.188^{* *} \\
(22.281)\end{array}$ & & & \\
\hline
\end{tabular}


Table 5 (continued)

\begin{tabular}{|c|c|c|c|c|c|}
\hline & & & insurance der & & \\
\hline & (6) & (7) & (8) & (9) & (10) \\
\hline Climatological (number) & & & $\begin{array}{l}6.922 * * \\
(21.402)\end{array}$ & & \\
\hline Earthquake (number) & & & & $\begin{array}{l}1.029 * * \\
(2.823)\end{array}$ & \\
\hline Windstorm (number) & & & & & $\begin{array}{l}2.684 * * \\
(9.645)\end{array}$ \\
\hline Risk & $\begin{array}{l}1.133^{* *} \\
(5.285)\end{array}$ & $\begin{array}{c}3.821 * * \\
(13.070)\end{array}$ & $\begin{array}{l}1.053^{* *} \\
(4.564)\end{array}$ & $\begin{array}{l}1.807^{* * *} \\
(8.370)\end{array}$ & $\begin{array}{l}1.823 * * \\
(4.130)\end{array}$ \\
\hline Epidemic $\times$ risk & $\begin{array}{c}3.616^{* *} \\
(61.553)\end{array}$ & & & & \\
\hline Flood $\times$ risk & & $\begin{array}{c}2.822 * * \\
(23.129)\end{array}$ & & & \\
\hline Climatological $\times$ risk & & & $\begin{array}{l}1.670 * * \\
(23.368)\end{array}$ & & \\
\hline Earthquake $\times$ risk & & & & $\begin{array}{l}2.487 * * \\
(3.025)\end{array}$ & \\
\hline Windstorm $\times$ risk & & & & & $\begin{array}{l}66.058^{* *} \\
(10.592)\end{array}$ \\
\hline Real GDP & $\begin{array}{l}2.794 * * \\
(21.610)\end{array}$ & $\begin{array}{l}3.035^{* *} \\
(9.158)\end{array}$ & $\begin{array}{c}2.853 * * \\
(19.755)\end{array}$ & $\begin{array}{c}2.932 * * \\
(11.073)\end{array}$ & $\begin{array}{l}2.818 * * \\
(16.264)\end{array}$ \\
\hline Inflation rate & $\begin{array}{l}-17.613^{* *} \\
(-23.322)\end{array}$ & $\begin{array}{l}-23.013^{* *} \\
(-20.443)\end{array}$ & $\begin{array}{l}-13.012^{* *} \\
(-22.309)\end{array}$ & $\begin{array}{l}-9.111^{* *} \\
(-10.050)\end{array}$ & $\begin{array}{l}-11.149^{* *} \\
(-12.215)\end{array}$ \\
\hline Interest rate & $\begin{array}{l}-43.838 * * \\
(-12.681)\end{array}$ & $\begin{array}{l}-36.342^{* *} \\
(-9.049)\end{array}$ & $\begin{array}{l}-50.033 * * \\
(-32.976)\end{array}$ & $\begin{array}{l}-49.046^{* *} \\
(-14.336)\end{array}$ & $\begin{array}{l}-49.375^{* *} \\
(-31.719)\end{array}$ \\
\hline Health expenditure & $\begin{array}{l}-6.246^{* *} \\
(-8.491)\end{array}$ & $\begin{array}{l}-1.048 * * \\
(-9.753)\end{array}$ & $\begin{array}{l}-1.062 * * \\
(-8.599)\end{array}$ & $\begin{array}{c}-9.100 * * \\
(-11.839)\end{array}$ & $\begin{array}{l}-9.473 * * \\
(-4.608)\end{array}$ \\
\hline Dependency ratio & $\begin{array}{l}-8.471 * * \\
(-12.924)\end{array}$ & $\begin{array}{l}-1.038 * * \\
(-9.782)\end{array}$ & $\begin{array}{c}-1.021 * * \\
(-36.404)\end{array}$ & $\begin{array}{c}-9.880 * * \\
(-19.535)\end{array}$ & $\begin{array}{l}-9.925^{* *} \\
(-20.824)\end{array}$ \\
\hline Arellano-Bond test (1) & 0.001 & 0.002 & 0.001 & 0.000 & 0.000 \\
\hline Arellano-Bond test (2) & 0.432 & 0.341 & 0.341 & 0.432 & 0.333 \\
\hline Hansen test & 0.107 & 0.130 & 0.123 & 0.325 & 0.394 \\
\hline & & No & e insurance & & \\
\hline & (11) & (12) & (13) & (14) & (15) \\
\hline Lagged dependent variables & $\begin{array}{l}0.503^{* *} \\
(3.520)\end{array}$ & $\begin{array}{c}0.594^{*} \\
(7.615)\end{array}$ & $\begin{array}{l}0.599 * * \\
(5.225)\end{array}$ & $\begin{array}{l}0.501^{* *} \\
(2.945)\end{array}$ & $\begin{array}{l}0.506^{* *} \\
(3.147)\end{array}$ \\
\hline Epidemic (number) & $\begin{array}{l}1.490 * * \\
(5.704)\end{array}$ & & & & \\
\hline Flood (number) & & $\begin{array}{c}0.800 \\
(1.033)\end{array}$ & & & \\
\hline Climatological (number) & & & $\begin{array}{l}5.753 * * \\
(3.528)\end{array}$ & & \\
\hline Earthquake (number) & & & & $\begin{array}{l}4.451 * * \\
(3.539)\end{array}$ & \\
\hline Windstorm (number) & & & & & $\begin{array}{l}5.751 * * \\
(3.780)\end{array}$ \\
\hline Risk & $\begin{array}{l}5.183^{* *} \\
(8.989)\end{array}$ & $\begin{array}{c}8.420^{*} \\
(1.915)\end{array}$ & $\begin{array}{l}4.506^{* *} \\
(6.196)\end{array}$ & $\begin{array}{l}5.767 * * \\
(5.940)\end{array}$ & $\begin{array}{l}6.025^{* *} \\
(4.920)\end{array}$ \\
\hline
\end{tabular}


Table 5 (continued)

\begin{tabular}{|c|c|c|c|c|c|}
\hline \multirow{3}{*}{$\overline{\text { Epidemic } \times \text { risk }}$} & \multicolumn{5}{|c|}{ Non-life insurance density } \\
\hline & (11) & (12) & (13) & (14) & $(15)$ \\
\hline & $\begin{array}{l}3.337 * * \\
(6.478)\end{array}$ & & & & \\
\hline Flood $\times$ risk & & $\begin{array}{c}1.845 \\
(1.209)\end{array}$ & & & \\
\hline Climatological $\times$ risk & & & $\begin{array}{c}1.494^{*} \\
(1.668)\end{array}$ & & \\
\hline Earthquake $\times$ risk & & & & $\begin{array}{l}1.678 * \\
(1.656)\end{array}$ & \\
\hline Windstorm $\times$ risk & & & & & $\begin{array}{l}3.101 * * \\
(3.710)\end{array}$ \\
\hline Real GDP & $\begin{array}{c}5.946^{*} \\
(1.750)\end{array}$ & $\begin{array}{l}17.806 \\
(1.484)\end{array}$ & $\begin{array}{c}1.793 \\
(0.511)\end{array}$ & $\begin{array}{l}7.296 * * \\
(3.205)\end{array}$ & $\begin{array}{l}14.292 * * \\
(3.439)\end{array}$ \\
\hline Inflation rate & $\begin{array}{c}-6.421 * * \\
(-11.123)\end{array}$ & $\begin{array}{l}-6.331 * * \\
(-6.953)\end{array}$ & $\begin{array}{c}-6.616 * * \\
(-29.879)\end{array}$ & $\begin{array}{c}-7.404 * * \\
(-20.674)\end{array}$ & $\begin{array}{c}-7.072 * * \\
(-31.034)\end{array}$ \\
\hline Interest rate & $\begin{array}{l}-22.509 * * \\
(-22.571)\end{array}$ & $\begin{array}{l}-26.217 * * \\
(-35.309)\end{array}$ & $\begin{array}{l}-24.302^{* *} \\
(-28.989)\end{array}$ & $\begin{array}{l}-23.940 * * \\
(-46.341)\end{array}$ & $\begin{array}{l}-22.481^{* *} \\
(-30.974)\end{array}$ \\
\hline Health expenditure & $\begin{array}{l}-57.831^{* *} \\
(-38.424)\end{array}$ & $\begin{array}{l}-60.561 * * \\
(-2.747)\end{array}$ & $\begin{array}{l}-55.433^{* *} \\
(-17.804)\end{array}$ & $\begin{array}{l}-61.067 * * \\
(-13.604)\end{array}$ & $\begin{array}{l}-64.470 * * \\
(-17.035)\end{array}$ \\
\hline Dependency ratio & $\begin{array}{l}-1.564 * * \\
(-2.232)\end{array}$ & $\begin{array}{c}-1.347 \\
(-0.774)\end{array}$ & $\begin{array}{l}-0.719^{*} \\
(-1.799)\end{array}$ & $\begin{array}{c}0.959 \\
(0.542)\end{array}$ & $\begin{array}{l}-1.406^{*} \\
(-1.817)\end{array}$ \\
\hline Arellano-Bond test (1) & 0.001 & 0.001 & 0.002 & 0.000 & 0.001 \\
\hline Arellano-Bond test (2) & 0.199 & 0.103 & 0.223 & 0.436 & 0.231 \\
\hline Hansen test & 0.254 & 0.241 & 0.207 & 0.228 & 0.213 \\
\hline
\end{tabular}

Notes: The natural disaster variables correspond to the incidences (number) of natural disasters that occurred. The regressions include a constant term. The $t$-values are in parentheses. ${ }^{*}$ and $*$ indicate the statistical significance at the 5 per cent and 10 per cent levels, respectively.

associated with higher total insurance penetration and non-life insurance penetration, while only a rise in the number of epidemic, flood, earthquake and climatological disasters stimulate the demand for life insurance penetration (Table 6). As such, our findings suggest that the occurrence (number) of natural disasters contribute to the development of insurance markets.

Moreover, we investigate whether deaths attributable to these five natural disaster variables impact the demand for total insurance, as well as life insurance and non-life insurance. The GMM regression estimates for the dependent variables' total insurance density (columns 1-5), life insurance density (columns 6-10) and non-life insurance density (columns 11-15) are presented in Table 7, while the GMM regression estimates for the dependent variables' total insurance penetration (columns 1-5), life insurance penetration (columns 6-10) and non-life insurance penetration (columns 11-15) are displayed in Table 8. We provide evidence that deaths attributable to epidemic, climatological disasters and windstorm significantly promote total insurance density. Also, we find that deaths caused by epidemic, flood, climatological disasters and windstorm increases life insurance density, whereas deaths caused only by climatological disasters and windstorm contributes to higher non-life insurance density (Table 7). 
Table 6 GMM regression estimates: Insurance penetration

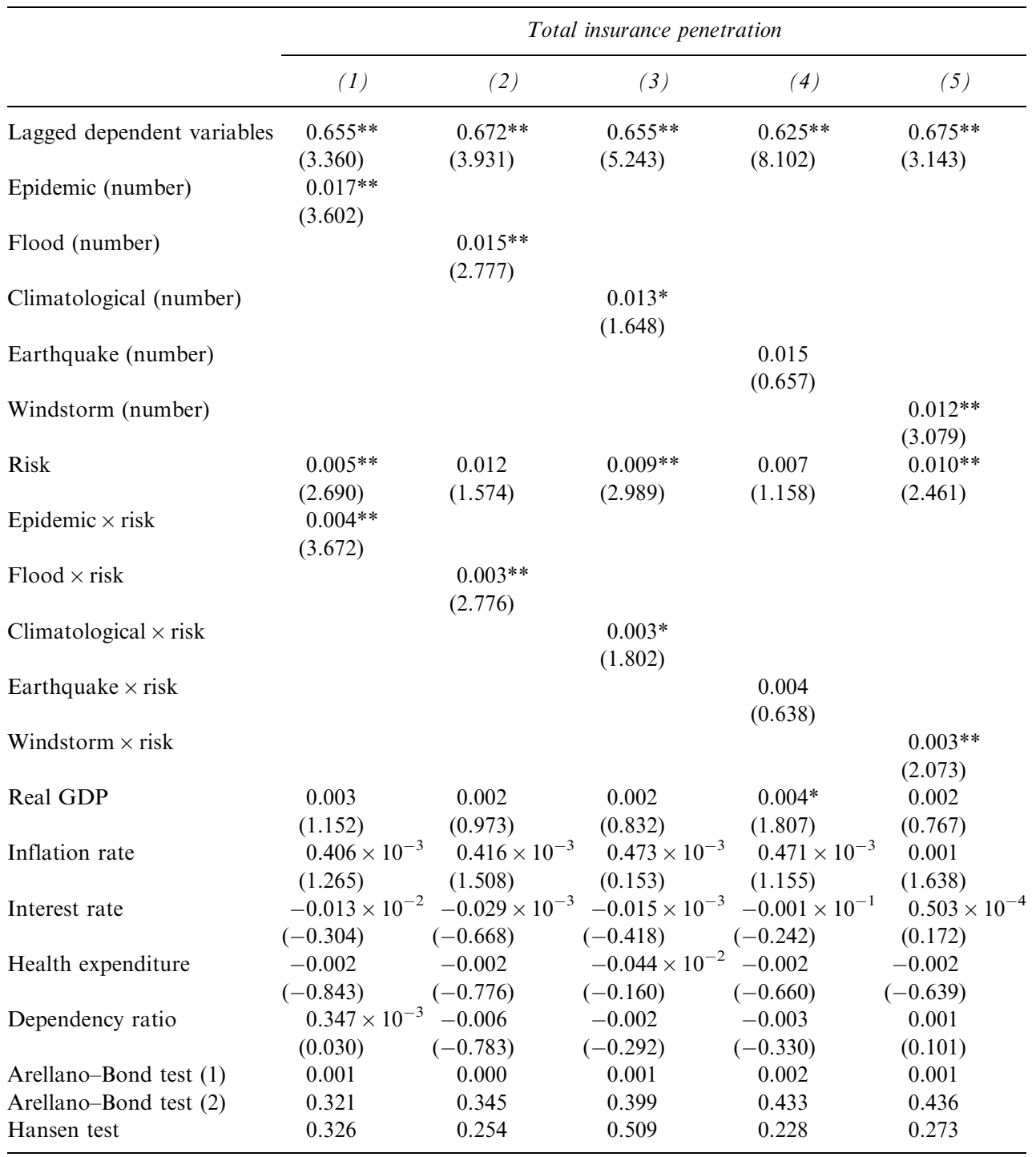

\begin{tabular}{lccccc}
\hline & \multicolumn{5}{c}{ Life insurance penetration } \\
\cline { 2 - 6 } & $(6)$ & $(7)$ & $(8)$ & $(9)$ & $(10)$ \\
\hline Lagged dependent variables & $\begin{array}{c}0.668^{* *} \\
(5.754)\end{array}$ & $0.615^{* *}$ & $0.669^{* *}$ & $0.689^{* *}$ & $0.684^{* *}$ \\
Epidemic (number) & $0.022^{*}$ & $(3.860)$ & $(6.728)$ & $(2.249)$ & $(5.682)$ \\
Flood (number) & $(1.729)$ & & & & \\
& & $0.008^{*}$ & & & \\
\hline
\end{tabular}


Table 6 (continued)

\begin{tabular}{|c|c|c|c|c|c|}
\hline & \multicolumn{5}{|c|}{ Life insurance penetration } \\
\hline & (6) & (7) & (8) & (9) & $(10)$ \\
\hline Climatological (number) & & & $\begin{array}{l}0.030 * * \\
(4.173)\end{array}$ & & \\
\hline Earthquake (number) & & & & $\begin{array}{l}0.020^{* * *} \\
(2.126)\end{array}$ & \\
\hline Windstorm (number) & & & & & $\begin{array}{c}0.003 \\
(0.386)\end{array}$ \\
\hline Risk & $\begin{array}{l}0.023^{* *} \\
(4.047)\end{array}$ & $\begin{array}{c}0.007 \\
(1.510)\end{array}$ & $\begin{array}{l}0.022 * * \\
(3.191)\end{array}$ & $\begin{array}{c}0.010 \\
(1.121)\end{array}$ & $\begin{array}{l}0.019 * * \\
(2.728)\end{array}$ \\
\hline Epidemic $\times$ risk & $\begin{array}{c}0.006^{*} \\
(1.806)\end{array}$ & & & & \\
\hline Flood $\times$ risk & & $\begin{array}{c}0.002 * \\
(1.853)\end{array}$ & & & \\
\hline Climatological $\times$ risk & & & $\begin{array}{l}0.007 * * \\
(4.323)\end{array}$ & & \\
\hline Earthquake $\times$ risk & & & & $\begin{array}{l}0.005^{* *} \\
(2.150)\end{array}$ & \\
\hline Windstorm $\times$ risk & & & & & $\begin{array}{c}0.001 \\
(0.442)\end{array}$ \\
\hline Real GDP & $\begin{array}{l}-0.045 \times 10^{-3} \\
(-0.274)\end{array}$ & $\begin{array}{c}0.001 \\
(1.190)\end{array}$ & $\begin{array}{c}0.002 \\
(0.690)\end{array}$ & $\begin{array}{l}-0.130 \times 10^{-3} \\
(-0.051)\end{array}$ & $\begin{array}{c}0.001 \\
(0.293)\end{array}$ \\
\hline Inflation rate & $\begin{array}{l}-0.379 \times 10^{-3 *} \\
(-1.748)\end{array}$ & $\begin{array}{l}-0.001 * * \\
(-3.574)\end{array}$ & $\begin{array}{l}0.183 \times 10^{-3} \\
(0.536)\end{array}$ & $\begin{array}{l}0.141 \times 10^{-3} \\
(0.479)\end{array}$ & $\begin{array}{c}0.001 \\
(1.316)\end{array}$ \\
\hline Interest rate & $\begin{array}{l}-0.003 \times 10^{-1} \\
(-0.855)\end{array}$ & $\begin{array}{l}0.339 \times 10^{-3} \\
(1.332)\end{array}$ & $\begin{array}{c}-0.001 \\
(-1.452)\end{array}$ & $\begin{array}{l}-0.001^{* *} \\
(-2.530)\end{array}$ & $\begin{array}{l}-0.001 * \\
(-1.756)\end{array}$ \\
\hline Health expenditure & $\begin{array}{c}-0.003 \\
(-0.915)\end{array}$ & $\begin{array}{l}-0.004^{* *} \\
(-2.686)\end{array}$ & $\begin{array}{l}-0.005 \\
(-1.377)\end{array}$ & $\begin{array}{l}-0.003 \\
(-0.860)\end{array}$ & $\begin{array}{l}-0.004 \\
(-0.834)\end{array}$ \\
\hline Dependency ratio & $\begin{array}{c}-0.010 * \\
(1.926)\end{array}$ & $\begin{array}{c}0.002 \\
(0.499)\end{array}$ & $\begin{array}{c}0.007 \\
(0.967)\end{array}$ & $\begin{array}{l}-0.021 * * \\
(-3.141)\end{array}$ & $\begin{array}{c}0.011 \\
(1.394)\end{array}$ \\
\hline Arellano-Bond test (1) & 0.002 & 0.001 & 0.001 & 0.000 & 0.001 \\
\hline Arellano-Bond test (2) & 0.334 & 0.443 & 0.454 & 0.412 & 0.422 \\
\hline Hansen test & 0.270 & 0.318 & 0.396 & 0.218 & 0.199 \\
\hline
\end{tabular}

\begin{tabular}{lccccc}
\hline & \multicolumn{5}{c}{ Non-life insurance penetration } \\
\cline { 2 - 6 } & $(11)$ & $(12)$ & $(13)$ & $(14)$ & $(15)$ \\
\hline Lagged dependent & $0.611^{* *}$ & $0.620^{* *}$ & $0.655^{* *}$ & $0.691^{* *}$ & $0.696^{* *}$ \\
variables & $(7.802)$ & $(2.458)$ & $(3.873)$ & $(4.096)$ & $(3.617)$ \\
Epidemic (number) & $0.010^{* *}$ & & & & \\
& $(6.604)$ & $0.006^{* *}$ & & & \\
Flood (number) & & $(2.041)$ & $0.433 \times 10^{-3 * *}$ & \\
Climatological & & $(2.150)$ & 0.005 & \\
(number) & & & $(1.246)$ & $0.002^{* *}$ \\
Earthquake (number) & & & & $(4.675)$ \\
Windstorm (number) & & & & \\
& & & & \\
\end{tabular}




\begin{tabular}{|c|c|c|c|c|c|}
\hline & \multicolumn{5}{|c|}{ Non-life insurance penetration } \\
\hline & (11) & (12) & (13) & (14) & $(15)$ \\
\hline Risk & $\begin{array}{c}-0.001 \\
(-0.337)\end{array}$ & $\begin{array}{c}0.004 \\
(1.356)\end{array}$ & $\begin{array}{l}0.159 \times 10^{-3} \\
(0.156)\end{array}$ & $\begin{array}{l}0.002 * * \\
(3.041)\end{array}$ & $\begin{array}{l}0.002^{* *} \\
(3.281)\end{array}$ \\
\hline Epidemic $\times$ risk & $\begin{array}{l}0.003^{* *} \\
(6.867)\end{array}$ & & & & \\
\hline Flood $\times$ risk & & $\begin{array}{l}0.001 * * \\
(2.071)\end{array}$ & & & \\
\hline Climatological $\times$ risk & & & $\begin{array}{l}0.211 \times 10^{-3 *} \\
(3.316)\end{array}$ & & \\
\hline Earthquake $\times$ risk & & & & $\begin{array}{c}0.001 \\
(1.318)\end{array}$ & \\
\hline Windstorm $\times$ risk & & & & & $\begin{array}{l}0.379 \times 10^{-3 * *} \\
(3.675)\end{array}$ \\
\hline Real GDP & $\begin{array}{l}0.002 * * \\
(3.252)\end{array}$ & $\begin{array}{l}-0.088 \times 10^{-3} \\
(-0.126)\end{array}$ & $\begin{array}{l}3.001 * * \\
(2.055)\end{array}$ & $\begin{array}{l}0.002 * * \\
(2.320)\end{array}$ & $\begin{array}{l}0.001^{*} \\
(1.713)\end{array}$ \\
\hline Inflation rate & $\begin{array}{l}-0.374 \times 10^{-4} \\
(-0.369)\end{array}$ & $\begin{array}{l}-0.811 \times 10^{-4} \\
(-0.441)\end{array}$ & $\begin{array}{l}-0.131 \times 10^{-3} \\
(-1.085)\end{array}$ & $\begin{array}{l}0.152 \times 10^{-3} \\
(1.173)\end{array}$ & $\begin{array}{l}0.843 \times 10^{-4} \\
(0.600)\end{array}$ \\
\hline Interest rate & $\begin{array}{l}-0.372 \times 10^{-3} \text { * } \\
(-2.535)\end{array}$ & $\begin{array}{l}*^{*}-0.213 \times 10^{-3} \\
(-1.097)\end{array}$ & $\begin{array}{l}0.643 \times 10^{-4} \\
(0.540)\end{array}$ & $\begin{array}{l}-0.305 \times 10^{-3 * *} \\
(-2.601)\end{array}$ & $\begin{array}{l}0.186 \times 10^{-3} \\
(1.340)\end{array}$ \\
\hline Health expenditure & $\begin{array}{l}0.003^{* *} \\
(2.830)\end{array}$ & $\begin{array}{c}0.001 \\
(0.910)\end{array}$ & $\begin{array}{l}0.003 * * \\
(2.671)\end{array}$ & $\begin{array}{l}0.003^{* *} \\
(2.715)\end{array}$ & $\begin{array}{c}0.001 \\
(1.455)\end{array}$ \\
\hline Dependency ratio & $\begin{array}{l}-0.007 * * \\
(-1.997)\end{array}$ & $\begin{array}{c}-0.003 \\
(-1.258)\end{array}$ & $\begin{array}{l}-0.007 * * \\
(-1.987)\end{array}$ & $\begin{array}{l}-0.007 * * \\
(-2.041)\end{array}$ & $\begin{array}{c}-0.003 \\
(-1.144)\end{array}$ \\
\hline Arellano-Bond test (1) & 0.000 & 0.001 & 0.001 & 0.001 & 0.002 \\
\hline Arellano-Bond test (2) & 0.123 & 0.223 & 0.255 & 0.212 & 0.299 \\
\hline Hansen test & 0.353 & 0.269 & 0.105 & 0.069 & 0.111 \\
\hline
\end{tabular}

Notes: The natural disaster variables correspond to the incidences (number) of natural disasters that occurred. The regressions include a constant term. The $t$-values are in parentheses. ** and * indicate the statistical significance at the 5 per cent and 10 per cent levels, respectively.

Furthermore, our findings suggest that deaths attributable to epidemic, climatological disasters and windstorm are significantly associated with higher total insurance penetration (Table 8). Also, it appears that deaths caused only by flood and windstorm lead to greater life insurance penetration, while deaths attributable to only floods cause an increase in non-life insurance penetration (Table 8). Overall, we provide robust evidence that the incidences of natural disasters and natural disaster deaths persuade individuals to invest in necessary protective measures, that is, purchasing life insurance and non-life insurance products. Nevertheless, we discover that not all natural disaster variables stimulate the demand for life insurance and non-life insurance policies. Since these natural disasters are associated with different scales of economic and human losses, it is perhaps not surprising that not all natural disasters induce residents to purchase insurance to secure financial protection.

Overall, we find that the variable risk is positive and statistically significant at the 5 per cent level in most specifications in the total insurance density models (columns 1-5) in Tables 5 and 7. This effect is also positive and statistically significant at 
Table 7 GMM regression estimates: Insurance density

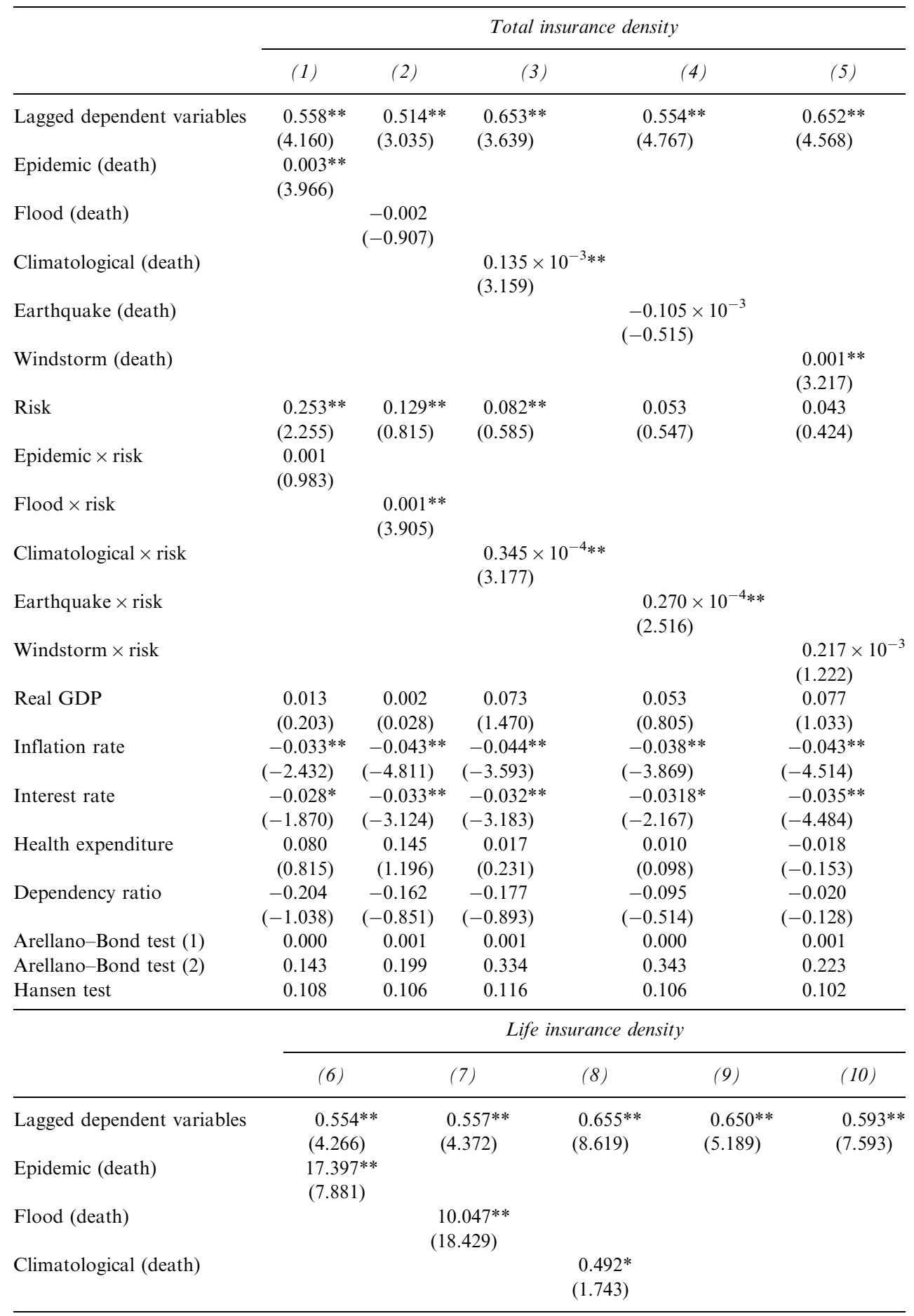


Table 7 (continued)

\begin{tabular}{|c|c|c|c|c|c|}
\hline & \multicolumn{5}{|c|}{ Life insurance density } \\
\hline & (6) & (7) & (8) & (9) & $(10)$ \\
\hline Earthquake (death) & & & & $\begin{array}{c}0.164 \\
(0.571)\end{array}$ & \\
\hline Windstorm (death) & & & & & $\begin{array}{l}2.405 * * \\
(6.033)\end{array}$ \\
\hline Risk & $\begin{array}{l}1.027 * * \\
(4.298)\end{array}$ & $\begin{array}{l}1.056^{* *} \\
(4.046)\end{array}$ & $\begin{array}{l}1.632 * * \\
(3.824)\end{array}$ & $\begin{array}{l}1.802 * * \\
(5.494)\end{array}$ & $\begin{array}{l}3.119 * * \\
(29.330)\end{array}$ \\
\hline Epidemic $\times$ risk & $\begin{array}{l}4.207 * * \\
(7.984)\end{array}$ & & & & \\
\hline Flood $\times$ risk & & $\begin{array}{c}2.439 * * \\
(18.443)\end{array}$ & & & \\
\hline Climatological $\times$ risk & & & $\begin{array}{c}0.114 \\
(1.467)\end{array}$ & & \\
\hline Earthquake $\times$ risk & & & & $\begin{array}{c}0.041 \\
(0.562)\end{array}$ & \\
\hline Windstorm $\times$ risk & & & & & $\begin{array}{l}0.587 * * \\
(6.506)\end{array}$ \\
\hline Real GDP & $\begin{array}{l}2.694^{* *} \\
(23.656)\end{array}$ & $\begin{array}{c}2.381^{* *} \\
(11.152)\end{array}$ & $\begin{array}{l}2.786^{* *} \\
(29.028)\end{array}$ & $\begin{array}{c}3.140 * * \\
(33.988)\end{array}$ & $\begin{array}{c}24.752 * \\
(1.643)\end{array}$ \\
\hline Inflation rate & $\begin{array}{l}-13.490 * * \\
(-33.387)\end{array}$ & $\begin{array}{l}-16.461^{* *} \\
(-13.099)\end{array}$ & $\begin{array}{l}-12.381 * * \\
(-8.924)\end{array}$ & $\begin{array}{l}-10.466^{* *} \\
(-18.637)\end{array}$ & $\begin{array}{l}-7.251 * * \\
(-7.204)\end{array}$ \\
\hline Interest rate & $\begin{array}{l}-45.904 * * \\
(-37.446)\end{array}$ & $\begin{array}{l}-45.862 * * \\
(-24.853)\end{array}$ & $\begin{array}{l}-42.390 * * \\
(-29.752)\end{array}$ & $\begin{array}{l}-43.798 * * \\
(-26.509)\end{array}$ & $\begin{array}{l}-43.205^{* *} \\
(-38.047)\end{array}$ \\
\hline Health expenditure & $\begin{array}{l}-90.783^{* *} \\
(-7.954)\end{array}$ & $\begin{array}{l}-94.433^{* *} \\
(-7.106)\end{array}$ & $\begin{array}{l}-92.364 * * \\
(-5.779)\end{array}$ & $\begin{array}{l}-10.050 * * \\
(-7.263)\end{array}$ & $\begin{array}{l}-10.017 * * \\
(-2.677)\end{array}$ \\
\hline Dependency ratio & $\begin{array}{c}-1.018 * * \\
(-22.661)\end{array}$ & $\begin{array}{c}-8.480 * * \\
(-17.188)\end{array}$ & $\begin{array}{c}-8.655^{* *} \\
(-50.368)\end{array}$ & $\begin{array}{c}-1.014 * * \\
(-20.033)\end{array}$ & $\begin{array}{l}-1.836^{* *} \\
(-7.327)\end{array}$ \\
\hline Arellano-Bond test (1) & 0.001 & 0.000 & 0.001 & 0.001 & 0.002 \\
\hline Arellano-Bond test (2) & 0.312 & 0.309 & 0.366 & 0.367 & 0.342 \\
\hline Hansen test & 0.102 & 0.308 & 0.604 & 0.157 & 0.183 \\
\hline & & Non & fe insurance a & sity & \\
\hline & (11) & (12) & (13) & (14) & (15) \\
\hline Lagged dependent variables & $\begin{array}{l}0.554^{* *} \\
(3.306)\end{array}$ & $\begin{array}{l}0.594 * * \\
(2.754)\end{array}$ & $\begin{array}{l}1.001 * * \\
(2.955)\end{array}$ & $\begin{array}{l}0.502 * * \\
(5.228)\end{array}$ & $\begin{array}{l}0.598 * * \\
(3.757)\end{array}$ \\
\hline Epidemic (death) & $\begin{array}{c}1.526 \\
(1.541)\end{array}$ & & & & \\
\hline Flood (death) & & $\begin{array}{c}0.247 \\
(1.241)\end{array}$ & & & \\
\hline Climatological (death) & & & $\begin{array}{l}1.515^{* *} \\
(7.935)\end{array}$ & & \\
\hline Earthquake (death) & & & & $\begin{array}{c}-0.277 \\
(-1.229)\end{array}$ & \\
\hline Windstorm (death) & & & & & $\begin{array}{l}1.538 * * \\
(5.579)\end{array}$ \\
\hline Risk & $\begin{array}{l}68.576^{* *} \\
(3.479)\end{array}$ & $\begin{array}{l}70.017 * * \\
(3.111)\end{array}$ & $\begin{array}{l}50.154 * * \\
(4.132)\end{array}$ & $\begin{array}{l}76.857 * * \\
(8.024)\end{array}$ & $\begin{array}{l}70.024 * * \\
(5.454)\end{array}$ \\
\hline
\end{tabular}


Table 7 (continued)

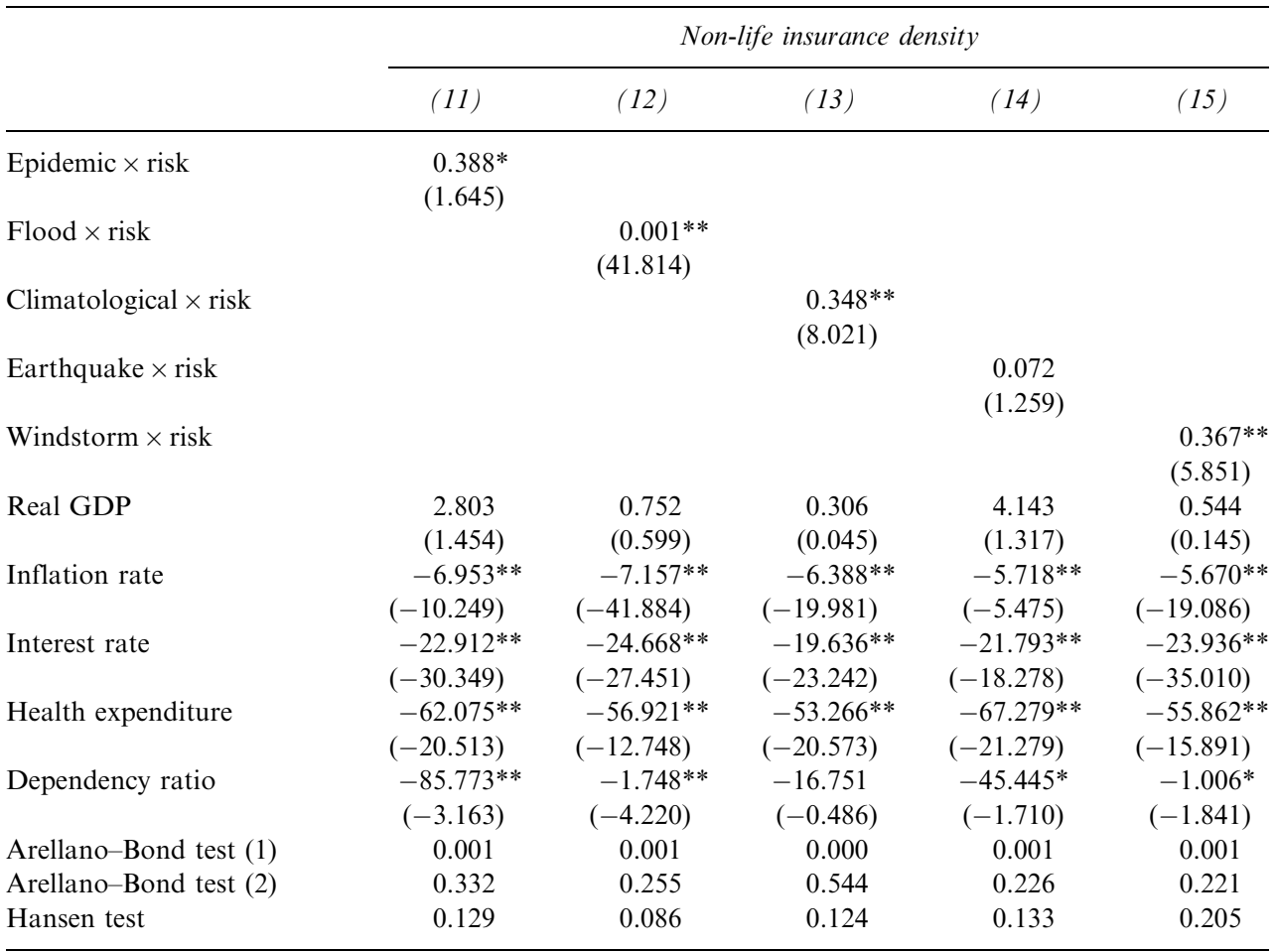

Notes: The natural disaster variables correspond to deaths caused by natural disasters. The regressions include a constant term. The $t$-values are in parentheses. ** and * indicate the statistical significance at the 5 per cent and 10 per cent levels, respectively.

conventional levels in all specifications in the life insurance density (columns 6-10) and non-life insurance density (columns 11-15) models in Tables 5 and 7. In general, we also find evidence that the political risk level of a country significantly impacts life insurance, non-life insurance and total insurance penetration (Tables 6 and 8). Hence, our results suggest that countries with lower levels of political risk experience greater insurance consumption. Our results are generally consistent with Ward and Zurbruegg, ${ }^{49}$ and Feyen et al., ${ }^{45}$ who show that countries with a higher quality legal environment experience life insurance market development. These findings are also broadly in line with Esho et al. ${ }^{63}$ and Feyen et al., ${ }^{45}$ who find that enforcement of legal rights contributes to higher non-life insurance consumption. ${ }^{96}$

As such, our results provide strong evidence that the political environment is an important determinant of insurance consumption across countries. More specifically,

${ }^{96}$ Also, Browne et al. (2000) find that the legal system is a significant determinant of non-life insurance development: OECD countries with common-law systems as compared to statutory-law systems experience higher motor vehicle and general liability insurance consumption. 
Table 8 GMM regression estimates: Insurance penetration

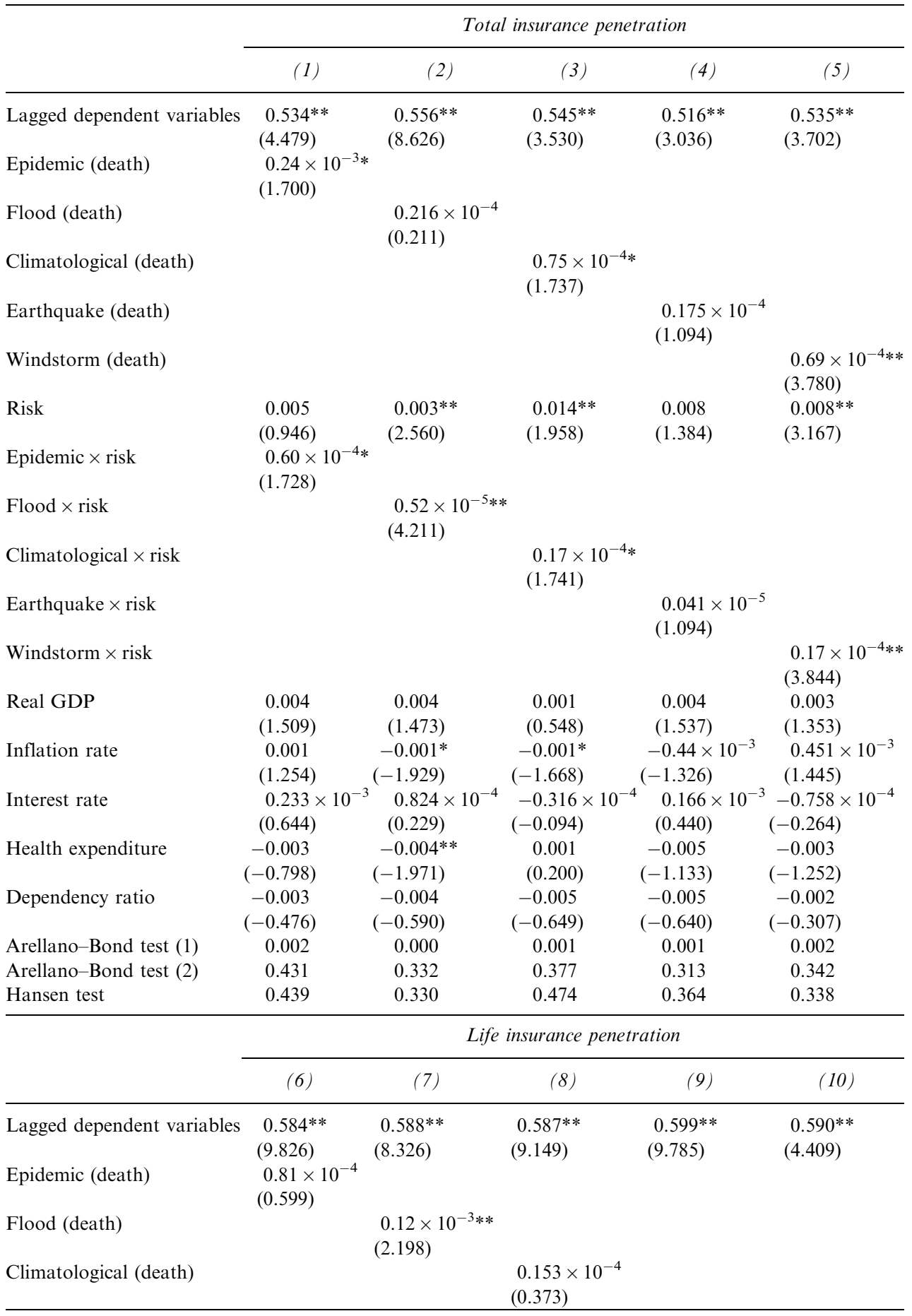


Table 8 (continued)

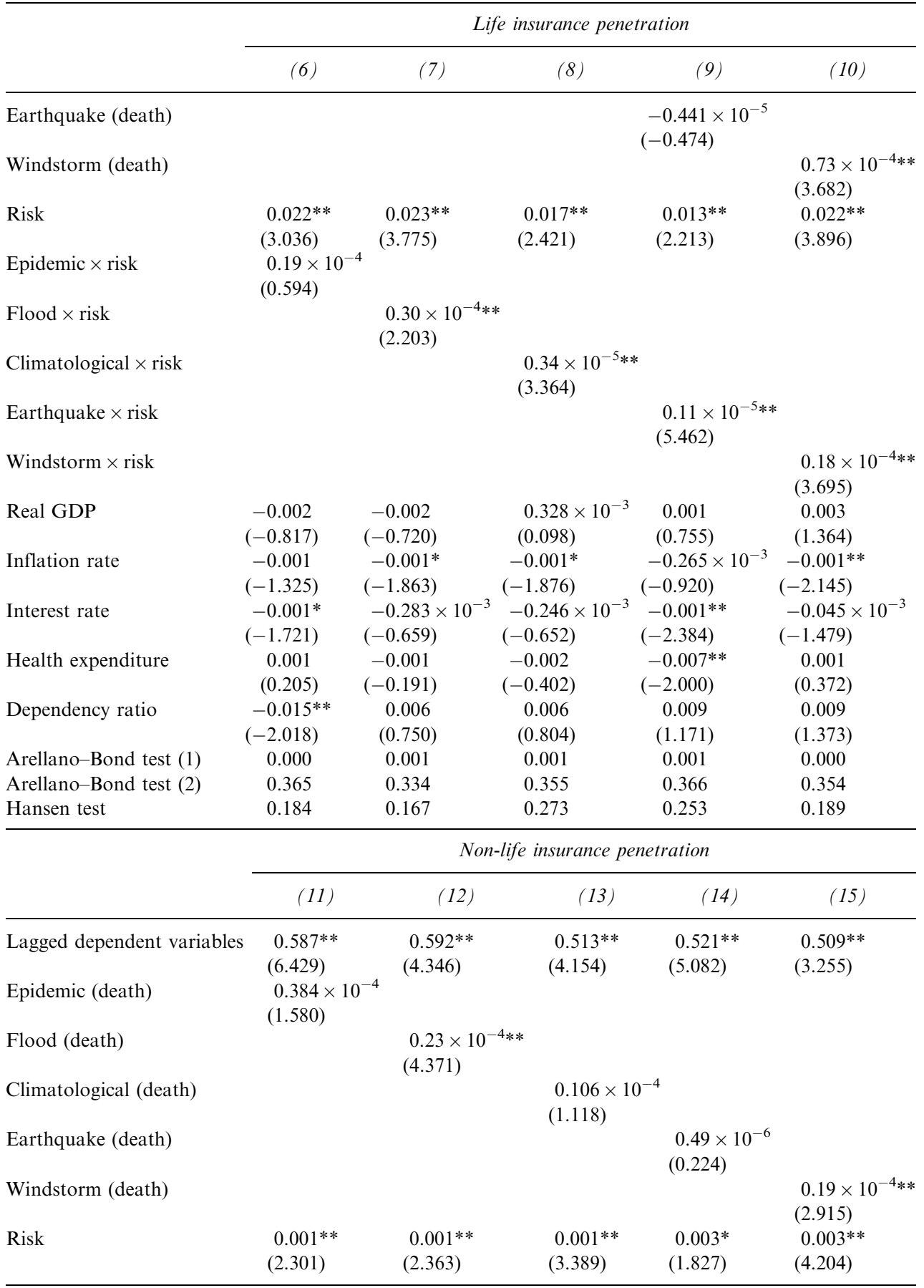


Table 8 (continued)

\begin{tabular}{|c|c|c|c|c|c|}
\hline & \multicolumn{5}{|c|}{ Non-life insurance penetration } \\
\hline & (11) & (12) & (13) & (14) & (15) \\
\hline Epidemic $\times$ risk & $\begin{array}{l}0.916 \times 10^{-5} \\
(1.550)\end{array}$ & & & & \\
\hline Flood $\times$ risk & & $\begin{array}{l}0.568 \times 10^{-5} \\
(1.379)\end{array}$ & & & \\
\hline Climatological $\times$ risk & & & $\begin{array}{l}0.239 \times 10^{-5} \\
(1.101)\end{array}$ & & \\
\hline Earthquake $\times$ risk & & & & $\begin{array}{l}0.12 \times 10^{-6} \\
(0.223)\end{array}$ & \\
\hline Windstorm $\times$ risk & & & & & $\begin{array}{l}0.47 \times 10^{-5 * *} \\
(3.006)\end{array}$ \\
\hline Real GDP & $\begin{array}{l}0.001 * * \\
(2.268)\end{array}$ & $\begin{array}{l}0.002 * * \\
(2.788)\end{array}$ & $\begin{array}{c}0.001 \\
(1.377)\end{array}$ & $\begin{array}{l}0.40 \times 10^{-3} \\
(1.020)\end{array}$ & $\begin{array}{l}0.001^{* *} \\
(2.188)\end{array}$ \\
\hline Inflation rate & $\begin{array}{l}-0.11 \times 10^{-3} \\
(-1.270)\end{array}$ & $\begin{array}{l}0.546 \times 10^{-4} \\
(0.639)\end{array}$ & $\begin{array}{l}-0.95 \times 10^{-4} \\
(-0.951)\end{array}$ & $\begin{array}{l}0.80 \times 10^{-4} \\
(0.697)\end{array}$ & $\begin{array}{l}-0.103 \times 10^{-4} \\
(-0.108)\end{array}$ \\
\hline Interest rate & $\begin{array}{l}0.122 \times 10^{-3} \\
(0.883)\end{array}$ & $\begin{array}{l}0.205 \times 10^{-3 *} \\
(1.714)\end{array}$ & $\begin{array}{l}0.182 \times 10^{-3} \\
(1.261)\end{array}$ & $\begin{array}{l}0.77 \times 10^{-4} \\
(0.486)\end{array}$ & $\begin{array}{l}0.811 \times 10^{-4} \\
(0.624)\end{array}$ \\
\hline Health expenditure & $\begin{array}{l}-0.002 * * \\
(-2.566)\end{array}$ & $\begin{array}{l}-0.002 * * \\
(-2.106)\end{array}$ & $\begin{array}{c}0.002 \\
(1.631)\end{array}$ & $\begin{array}{c}0.001 \\
(0.882)\end{array}$ & $\begin{array}{c}0.002 \\
(1.260)\end{array}$ \\
\hline Dependency ratio & $\begin{array}{l}-0.007 * * \\
(-2.850)\end{array}$ & $\begin{array}{l}-0.005^{*} \\
(-1.838)\end{array}$ & $\begin{array}{c}-0.004 \\
(-1.341)\end{array}$ & $\begin{array}{c}0.001 \\
(0.163)\end{array}$ & $\begin{array}{c}-0.003 \\
(-0.879)\end{array}$ \\
\hline Arellano-Bond test (1) & 0.002 & 0.001 & 0.000 & 0.001 & 0.001 \\
\hline Arellano-Bond test (2) & 0.224 & 0.298 & 0.212 & 0.223 & 0.230 \\
\hline Hansen test & 0.197 & 0.216 & 0.039 & 0.139 & 0.159 \\
\hline
\end{tabular}

Notes: The natural disaster variables correspond to deaths caused by natural disasters. The regressions include a constant term. The $t$-values are in parentheses. ** and * indicate the statistical significance at the 5 per cent and 10 per cent levels, respectively.

our findings suggest that countries with lower levels of political risk experience insurance market development. These results are certainly anticipated. For example, La Porta et al. ${ }^{97}$ find that the political environment of a country is a significant determinant of capital markets: economies with inferior investor protection are associated with smaller capital markets. Also, Levine ${ }^{98}$ shows that countries with a political environment that promotes "creditor rights" and thoroughly "enforces contracts" experience banking development (p. 1131). Furthermore, Levine ${ }^{99}$ finds that countries with a legal environment that "give a high priority to creditors receiving the full present value of their claims on corporations", "enforce contracts effectively", and "promote comprehensive and accurate financial reporting by corporations" experience financial development (p. 8).

\footnotetext{
${ }^{97}$ La Porta et al. (1997).

${ }^{98}$ Levine (1998).

${ }^{99}$ Levine (1999).
} 
Next, we investigate the interaction effects of our natural disaster variables and political risk. First, we examine whether the incidences of natural disasters impact insurance market development under the tenure of a government with different levels of political risk (Tables 5 and 6). As can be seen, all interaction effects between natural disaster variables and risk are positive and statistically significant at conventional levels in the total insurance density model (columns 1-5) and life insurance density model (columns 6-10) in Table 5. These results suggest that the incidences of natural disasters are associated with higher total insurance density in countries with lower levels of political risk. Furthermore, we provide evidence that the occurrences of epidemic, earthquake, windstorm and climatological disasters also contribute to greater non-life insurance density as the political risk level of a country falls, at least at the 10 per cent level of statistical significance (Table 5).

It appears that the natural disaster variables epidemic, flood, climatological disasters and windstorm also contribute to higher total insurance penetration as the political risk level of a country falls, at least at the 10 per cent level of statistical significance (Table 6). These findings are also the case in the non-life insurance penetration model, at the 5 per cent level of statistical significance (Table 6). Furthermore, the results suggest that an increase in the natural disaster variables epidemic, flood, climatological disasters and earthquake leads to higher life insurance penetration under the tenure of a government with low levels of political risk, at least at the 10 per cent level of statistical significance (column 6-10 in Table 6). In general, we provide evidence that the interaction effects between the incidences (number) of natural disasters and the political risk level of a country is a significant determinant of insurance market development.

Second, we analyse whether deaths caused by these five natural disasters influence the demand for insurance, including life insurance and non-life insurance, in countries with different levels of political risk (Tables 7 and 8). We find that deaths caused by flood, earthquake and climatological disasters lead to higher total insurance density under the tenure of a government with lower levels of political risk, at the 5 per cent level of statistical significance (Table 7). In addition, we discover that deaths attributable to the natural disaster variables epidemic, flood and windstorm contribute to higher life insurance density, whereas deaths caused by epidemic, flood, windstorm and climatological disasters are associated with greater non-life insurance density as the political risk level of a country falls, at least at the 10 per cent level of statistical significance (Table 7).

Finally, we find that deaths attributable to epidemic, flood, windstorm and climatological disasters increase total insurance penetration in countries with lower levels of political risk (Table 8). Also, we show that deaths caused by flood, earthquake, windstorm and climatological disasters lead to higher life insurance penetration under the tenure of a government with low levels of political risk (Table 8). Alternatively, our findings indicate that the interaction effects of our natural disaster variables and political risk have a limited impact on non-life insurance penetration, which is evident by the statistically insignificant coefficients in all equations (columns 11-15) in Table 8. While we show that the interaction effects of natural disaster variables and political risk are important determinants of insurance market development, our findings reveal that not all interaction effects are statistically significant at conventional levels. Nevertheless, we find evidence that the incidences of natural 
disasters and natural disaster deaths contribute to higher insurance consumption in countries with lower levels of political risk.

In effect, these results imply that the occurrences of natural disasters and deaths caused by natural disasters reduce the demand for insurance, as well as life insurance and non-life insurance, as the political risk level of a country rises. In this context, these findings suggest that a rise in the political risk level of a country mitigates the beneficial effect of natural disaster variables on insurance market development. In summary, we highlight the importance of natural disaster variables, the political risk level of a country and their interaction effects in stimulating total insurance consumption, together with life insurance and non-life insurance consumption. In general, our results are broadly in line with those of Oh and Reuveny, ${ }^{10}$ who find that the interaction effects of natural disasters and political risk significantly influence international trade. Also, as can be seen, the impacts of the control variables on insurance market development in the extended model (Tables 5-8) are mostly consistent with our baseline model (Tables 1-4).

\section{Conclusion}

We examine the relationship between natural disasters, political risk and insurance market development in a panel of 39 countries over the period 1984-2009 using a dynamic panel two-step system GMM model. We find that natural disasters are important determinants of insurance consumption across countries. In particular, we find that the incidences of natural disasters and deaths caused by natural disasters lead to greater total insurance, as well as life insurance and non-life insurance consumption. Our results therefore provide evidence that the occurrences of natural disasters and deaths attributable to natural disasters influence individuals to invest in appropriate protective measures, that is, purchase insurance policies.

However, we find that not all incidences of natural disasters and natural disaster deaths stimulate the demand for insurance products, including life insurance and nonlife insurance products. Given that floods, earthquakes, windstorms, epidemics and climatological disasters are associated with different scales of economic and human losses, our results that not all natural disasters induce individuals to purchase insurance policies to secure financial protection are perhaps not surprising. Nevertheless, we emphasise that natural disaster variables are important factors in insurance market development, and, therefore, it is imperative to account for these forces in developing and implementing effective insurance policy measures.

We also discover that countries with lower levels of political risk are associated with insurance market development. Furthermore, the incidences of natural disasters and deaths attributable to natural disasters lead to higher insurance consumption under the tenure of a government with lower levels of political risk. In other words, our findings suggest that the occurrences of natural disasters and natural disaster deaths reduce the demand for insurance, as well as life insurance and non-life insurance, as the political risk level of a country rises. Hence, these results indicate that a rise in the political risk level of a country mitigates the beneficial effect of natural disaster variables on insurance market development. 
This leads to important policy recommendations, as policymakers and insurance companies need to investigate more closely the causes of political risk across countries to promote the growth of insurance markets. Also, our findings emphasise that governments need to reduce the level of political risk in order to experience insurance market development. ${ }^{100}$ Certainly, the political environment of a country influences the investment activities of insurance companies. Therefore, our results suggest that insurance companies need to seek countries with lower levels of political risk to facilitate the demand for insurance products. In summary, our results provide evidence that natural disasters, political risk and their interaction effects are fundamental determinants of insurance consumption across countries.

\section{Acknowledgements}

We thank the editor and two anonymous referees for their helpful comments and suggestions. Chun-Ping Chang is grateful to the National Science Council of Taiwan for financial support through grant NSC 1012410-H-158-003. All remaining errors are our own.

\section{References}

Anderson, D.R. (1974) 'The national flood insurance program-Problems and potential', The Journal of Risk and Insurance 41(4): 579-599.

Arellano, M. and Bond, S. (1991) 'Some tests of specification for panel data: Monte Carlo evidence and an application to employment equations', The Review of Economic Studies 58(2): 277-297.

Arellano, M. and Bover, O. (1995) 'Another look at the instrumental-variable estimation of errorcomponents models', Journal of Econometrics 68(1): 29-52.

Arnold, M. (2008) 'The role of risk transfer and insurance in disaster risk reduction and climate change adaption', Policy Brief for the Commission on Climate Change and Development, from http://www.ccd commission.org/Filer $/$ pdf/pb_risk_transfer.pdf.

Athavale, M. and Avila, S.M. (2011) 'An analysis of the demand for earthquake insurance', Risk Management and Insurance Review 14(2): 233-246.

Baltagi, B.H. (1995) Econometric Analysis of Panel Data, New York: John Wiley \& Sons.

Beck, T., Levine, R. and Loayza, N. (2000) 'Finance and the sources of growth', Journal of Financial Economics 58(1-2): 261-300.

Beck, T. and Webb, I. (2003) 'Economic, demographic, and institutional determinants of life insurance consumption across countries', The World Bank Economic Review 17(1): 51-88.

Beenstock, M., Dickinson, G. and Khajuria, S. (1986) 'The determination of life premiums: An international cross-section analysis 1970-1981', Insurance: Mathematics and Economics 5(4): 261-270.

Beenstock, M., Dickinson, G. and Khajuria, S. (1988) 'The relationship between property-liability insurance premiums and income: An international analysis', The Journal of Risk and Insurance 55(2): 259-272.

Bellettini, G. (1998) 'Aggregate uncertainty, political instability and income redistribution', European Journal of Political Economy 14(1): 19-33.

Berrebi, C. and Ostwald, J. (2011) 'Earthquakes, hurricanes, and terrorism: Do natural disasters incite terror?' Public Choice 149(3-4): 383-403.

Besley, T. and Burgess, R. (2002) 'The political economy of government responsiveness: Theory and evidence from India', The Quarterly Journal of Economics 117(4): 1415-1451.

Bhavnani, R. (2006) Natural disaster conflicts, Working Paper, Harvard University.

100 This is particularly important, as the literature provides strong evidence that insurance market development leads to higher economic growth (see, for example, Lee, 2011). 
Blundell, R. and Bond, S. (1998) 'Initial conditions and moment restrictions in dynamic panel data models', Journal of Econometrics 87(1): 115-143.

Brancati, D. (2007) 'Political aftershocks: The impact of earthquakes on intrastate conflict', Journal of Conflict Resolution 51(5): 715-743.

Browne, M.J., Chung, J. and Frees, E.W. (2000) 'International property-liability insurance consumption', The Journal of Risk and Insurance 67(1): 73-90.

Browne, M.J. and Kim, K. (1993) 'An international analysis of life insurance demand', The Journal of Risk and Insurance 60(4): 616-634.

Busse, M. and Hefeker, C. (2007) 'Political risk, institutions and foreign direct investment', European Journal of Political Economy 23(2): 397-415.

Campbell, R.A. (1980) 'The demand for life insurance: An application of the economics of uncertainty', The Journal of Finance 35(5): 1155-1172.

Chang, C.P. and Berdiev, A.N. (2013) Do natural disasters increase the likelihood that a government is replaced? Working Paper.

Coate, S. (1995) 'Altruism, the Samaritan's dilemma, and government transfer policy', The American Economic Review 85(1): 46-57.

Cummins, J.D. and Mahul, O. (2009) Catastrophe Risk Financing in Developing Countries, Washington, DC: The World Bank.

Cutler, D.M. and Zeckhauser, R. (2004) 'Extending the theory to meet the practice of insurance', in R.E. Litan and R. Herring (eds.) Brookings-Wharton Papers on Financial Services, pp. 1-53.

Drury, A.C. and Olson, R.S. (1998) 'Disasters and political unrest: An empirical investigation', Journal of Contingencies and Crisis Management 6(3): 153-161.

Ember, C.R. and Ember, M. (1992) 'Resource unpredictability, mistrust, and war: A cross-cultural study', The Journal of Conflict Resolution 36(2): 242-262.

Emergency Events Database (2011) 'The OFDA/CRED international disaster database', www.emdat.net , Université Catholique de Louvain, Brussels, Belgium.

Enz, R. (2000) 'The S-curve relation between per-capita income and insurance penetration', The Geneva Papers on Risk and Insurance-Issues and Practice 25(3): 396-406.

Esho, N., Kirievsky, A., Ward, D. and Zurbruegg, R. (2004) 'Law and the determinants of property-casualty insurance', The Journal of Risk and Insurance 71(2): 265-283.

Feyen, E., Lester, R. and Rocha, R. (2011) What drives the development of the insurance sector? An empirical analysis based on a panel of developed and developing countries, World Bank Policy Research Working Paper 5572, Washington, DC: World Bank.

Gennaioli, N. and Shleifer, A. (2010) 'What comes to mind', The Quarterly Journal of Economics 125(4): 1399-1433.

Gerber, B.J. (2007) 'Disaster management in the United States: Examining key political and policy challenges', Policy Studies Journal 35(2): 227-238.

Hammond, J.D., Houston, D.B. and Melander, E.R. (1967) 'Determinants of household life insurance premium expenditures: An empirical investigation', The Journal of Risk and Insurance 34(3): 397-408.

Hussels, S., Ward, D. and Zurbruegg, R. (2005) 'Stimulating the demand for insurance', Risk Management and Insurance Review 8(2): 257-278.

Hwang, T. and Greenford, B. (2005) 'A cross-section analysis of the determinants of life insurance consumption in Mainland China, Hong Kong, and Taiwan', Risk Management and Insurance Review 8(1): 103-125.

International Country Risk Guide (2010) 'International country risk guide data', The Political Risk Services Group.

Kahn, M. (2005) 'The death toll from natural disasters: The role of income, geography, and institutions', The Review of Economics and Statistics 87(2): 271-284.

Klomp, J. and de Haan, J. (2009) 'Central bank independence and financial stability', Journal of Financial Stability 5(4): 321-338.

Kriesel, W. and Landry, C. (2004) 'Participation in the national flood insurance program: An empirical analysis for coastal properties', The Journal of Risk and Insurance 71(3): 405-420.

Kunreuther, H. (1974) 'Disaster insurance: A tool for hazard mitigation', The Journal of Risk and Insurance 41(2): 287-303.

Kunreuther, H. (1984) 'Causes of underinsurance against natural disasters', The Geneva Papers on Risk and Insurance-Issues and Practice 9(31): 206-220. 
Kunreuther, H. (1996) 'Mitigating disaster losses through insurance', Journal of Risk and Uncertainty 12(2-3): 171-187.

Kunreuther, H. (2008) 'Reducing losses from catastrophic risks through long-term insurance and mitigation', Social Research 75(3): 905-930.

Kunreuther, H. and Pauly, M. (2005) 'Insurance decision-making and market behavior', Foundations and Trends in Microeconomics 1(2): 63-127.

La Porta, R., Lopez-de-Silanes, F., Shleifer, A. and Vishny, R.W. (1997) 'Legal determinants of external finance', The Journal of Finance 52(3): 1131-1150.

Lee, C.C. (2011) 'Does insurance matter for growth: Empirical evidence from OECD countries', The B.E. Journal of Macroeconomics 11(1): 1-28.

Levine, R. (1998) 'The legal environment, banks, and long-run economic growth', Journal of Money, Credit \& Banking 30(3): 596-613.

Levine, R. (1999) 'Law, finance, and economic growth', Journal of Financial Intermediation 8(1-2): 8-35.

Li, D., Moshirian, F., Nguyen, P. and Wee, T. (2007) 'The demand for life insurance in OECD countries', The Journal of Risk and Insurance 74(3): 637-652.

Michel-Kerjan, E.O. and Kousky, C. (2010) 'Come rain or shine: Evidence on flood insurance purchases in Florida', The Journal of Risk and Insurance 77(2): 369-397.

Miguel, E., Satyanath, S. and Sergenti, E. (2004) 'Economic shocks and civil conflict: An instrumental variables approach', Journal of Political Economy 112(4): 725-753.

Nel, P. and Righarts, M. (2008) 'Natural disasters and the risk of violent civil conflict', International Studies Quarterly 52(1): 159-185.

Noy, I. (2009) 'The macroeconomic consequences of disasters', Journal of Development Economics 88(2): 221-231.

Noy, I. and Vu, T.B. (2010) 'The economics of natural disasters in a developing country: The case of Vietnam', Journal of Asian Economics 21(4): 345-354.

Oh, C.H. and Reuveny, R. (2010) 'Climatic natural disasters, political risk, and international trade', Global Environmental Change 20(2): 243-254.

Olson, R.S. and Drury, A.C. (1997) 'Un-therapeutic communities: A cross-national analysis of post-disaster political unrest', International Journal of Mass Emergencies and Disasters 15(2): 221-238.

Outreville, J.F. (1996) 'Life insurance markets in developing countries', The Journal of Risk and Insurance 63(2): $263-278$.

Raddatz, C. (2007) 'Are external shocks responsible for the instability of output in low-income countries?' Journal of Development Economics 84(1): 155-187.

Ramcharan, R. (2007) 'Does the exchange rate regime matter for real shocks? Evidence from windstorms and earthquakes', Journal of International Economics 73(1): 31-47.

Raschky, P.A., Schwarze, R., Schwindt, M. and Zahn, F. (2013) 'Uncertainty of government relief and the crowding out of flood insurance', Environmental and Resource Economics 54(2): 179-200.

Roodman, D. (2009) 'How to do xtabond2: An introduction to difference and system GMM in Stata', Stata Journal 9(1): 86-136.

Schwarze, R. and Wagner, G.G. (2004) 'In the aftermath of Dresden: New directions in German flood insurance', The Geneva Papers on Risk and Insurance-Issues and Practice 29(2): 154-168.

Schwarze, R. and Wagner, G.G. (2007) 'The political economy of natural disaster insurance: Lessons from the failure of a proposed compulsory insurance scheme in Germany', European Environment 17(6): 403-415.

Sobel, R.S. and Leeson, P.T. (2006) 'Government's response to Hurricane Katrina: A public choice analysis', Public Choice 127(1-2): 55-73.

Sobel, R.S. and Leeson, P.T. (2007) 'The use of knowledge in natural-disaster relief management', The Independent Review 11(4): 519-532.

Strobl, E. (2012) 'The economic growth impact of natural disasters in developing countries: Evidence from hurricane strikes in the Central American and Caribbean regions', Journal of Development Economics 97(1): 130-141.

Swiss Reinsurance Company (2011) Zurich, Switzerland: Swiss Reinsurance Company.

Swiss Reinsurance Company (2012) Natural Catastrophes and Man-made Disasters in 2011: Historic Losses Surface from Record Earthquakes and Floods. Sigma No. 2/2012, Zurich, Switzerland: Swiss Reinsurance Company. 
Toya, H. and Skidmore, M. (2007) 'Economic development and the impacts of natural disasters', Economic Letters 94(1): 20-25.

Truett, D.B. and Truett, L.J. (1990) 'The demand for life insurance in Mexico and the United States: A comparative study', The Journal of Risk and Insurance 57(2): 321-328.

Ward, D. and Zurbruegg, R. (2002) 'Law, politics and life insurance consumption in Asia', The Geneva Papers on Risk and Insurance-Issues and Practice 27(3): 395-412.

World Bank (2011) World Development Indicators, Washington, DC: The World Bank.

Zeckhauser, R. (1995) 'Insurance and catastrophes', The Geneva Papers on Risk and Insurance-Issues and Practice 20(2): 157-175.

Zietz, E.N. (2003) 'An examination of the demand for life insurance', Risk Management and Insurance Review 6(2): 159-191.

\section{Appendix}

Table A1 Data definitions, sources and descriptive statistics

\begin{tabular}{|c|c|c|c|c|c|c|}
\hline Variable & Definition & Source & $\begin{array}{l}\text { Predicted } \\
\text { sign }\end{array}$ & Mean & $\begin{array}{l}\text { Standard } \\
\text { deviation }\end{array}$ & Observations \\
\hline $\begin{array}{l}\text { Total } \\
\text { insurance } \\
\text { penetration }\end{array}$ & $\begin{array}{l}\text { Total insurance premiums } \\
\text { as a percentage of GDP }\end{array}$ & $\begin{array}{l}\text { Swiss Reinsurance } \\
\text { Company (2011) }\end{array}$ & & 0.058 & 0.051 & 1014 \\
\hline $\begin{array}{l}\text { Life insurance } \\
\text { penetration }\end{array}$ & $\begin{array}{l}\text { Life insurance premiums as } \\
\text { a percentage of GDP }\end{array}$ & $\begin{array}{l}\text { Swiss Reinsurance } \\
\text { Company (2011) }\end{array}$ & & 0.035 & 0.043 & 1014 \\
\hline $\begin{array}{l}\text { Non-life } \\
\text { insurance } \\
\text { penetration }\end{array}$ & $\begin{array}{l}\text { Non-life insurance } \\
\text { premiums as a percentage } \\
\text { of GDP }\end{array}$ & $\begin{array}{l}\text { Swiss Reinsurance } \\
\text { Company (2011) }\end{array}$ & & 0.023 & 0.013 & 1014 \\
\hline $\begin{array}{l}\text { Total } \\
\text { insurance } \\
\text { density }\end{array}$ & $\begin{array}{l}\text { (Log) real total insurance } \\
\text { premiums per capita }\end{array}$ & $\begin{array}{l}\text { Swiss Reinsurance } \\
\text { Company (2011) }\end{array}$ & & 983.99 & 2518.98 & 1014 \\
\hline $\begin{array}{l}\text { Life insurance } \\
\text { density }\end{array}$ & $\begin{array}{l}\text { (Log) real life insurance } \\
\text { premiums per capita }\end{array}$ & $\begin{array}{l}\text { Swiss Reinsurance } \\
\text { Company (2011) }\end{array}$ & & 336.13 & 25.854 & 1014 \\
\hline $\begin{array}{l}\text { Non-life } \\
\text { insurance } \\
\text { density }\end{array}$ & $\begin{array}{l}\text { (Log) real non-life } \\
\text { insurance premiums per } \\
\text { capita }\end{array}$ & $\begin{array}{l}\text { Swiss Reinsurance } \\
\text { Company (2011) }\end{array}$ & & 647.86 & 1052.30 & 1014 \\
\hline $\begin{array}{l}\text { Epidemic } \\
\text { (number) }\end{array}$ & $\begin{array}{l}\text { The number of epidemic } \\
\text { disasters occurred }\end{array}$ & $\begin{array}{l}\text { Emergency Events } \\
\text { Database (2011) }\end{array}$ & + & 0.203 & 0.681 & 1014 \\
\hline $\begin{array}{l}\text { Flood } \\
\text { (number) }\end{array}$ & $\begin{array}{l}\text { The number of floods } \\
\text { occurred }\end{array}$ & $\begin{array}{l}\text { Emergency Events } \\
\text { Database (2011) }\end{array}$ & + & 1.251 & 2.129 & 1014 \\
\hline $\begin{array}{l}\text { Climatological } \\
\text { (number) }\end{array}$ & $\begin{array}{l}\text { The number of } \\
\text { climatological disasters } \\
\text { occurred }\end{array}$ & $\begin{array}{l}\text { Emergency Events } \\
\text { Database (2011) }\end{array}$ & + & 0.395 & 0.873 & 1014 \\
\hline $\begin{array}{l}\text { Earthquake } \\
\text { (number) }\end{array}$ & $\begin{array}{l}\text { The number of earthquakes } \\
\text { occurred }\end{array}$ & $\begin{array}{l}\text { Emergency Events } \\
\text { Database (2011) }\end{array}$ & + & 0.342 & 0.920 & 1014 \\
\hline $\begin{array}{l}\text { Windstorm } \\
\text { (number) }\end{array}$ & $\begin{array}{l}\text { The number of windstorms } \\
\text { occurred }\end{array}$ & $\begin{array}{l}\text { Emergency Events } \\
\text { Database (2011) }\end{array}$ & + & 1.175 & 2.722 & 1014 \\
\hline $\begin{array}{l}\text { Epidemic } \\
\text { (deaths) }\end{array}$ & $\begin{array}{l}\text { Deaths caused by epidemic } \\
\text { disasters }\end{array}$ & $\begin{array}{l}\text { Emergency Events } \\
\text { Database (2011) }\end{array}$ & + & 25.28 & 221.14 & 1014 \\
\hline Flood (deaths) & Deaths caused by floods & $\begin{array}{l}\text { Emergency Events } \\
\text { Database (2011) }\end{array}$ & + & 92.74 & 976.74 & 1014 \\
\hline $\begin{array}{l}\text { Climatological } \\
\text { (deaths) }\end{array}$ & $\begin{array}{l}\text { Deaths caused by } \\
\text { climatological disasters }\end{array}$ & $\begin{array}{l}\text { Emergency Events } \\
\text { Database (2011) }\end{array}$ & + & 81.53 & 1012.03 & 1014 \\
\hline $\begin{array}{l}\text { Earthquake } \\
\text { (deaths) }\end{array}$ & $\begin{array}{l}\text { Deaths caused by } \\
\text { earthquakes }\end{array}$ & $\begin{array}{l}\text { Emergency Events } \\
\text { Database (2011) }\end{array}$ & + & 301.41 & 5371.74 & 1014 \\
\hline
\end{tabular}


Table A1 (continued)

\begin{tabular}{|c|c|c|c|c|c|c|}
\hline Variable & Definition & Source & $\begin{array}{l}\text { Predicted } \\
\text { sign }\end{array}$ & Mean & $\begin{array}{l}\text { Standard } \\
\text { deviation }\end{array}$ & Observations \\
\hline $\begin{array}{l}\text { Windstorm } \\
\text { (deaths) }\end{array}$ & $\begin{array}{l}\text { Deaths caused by } \\
\text { windstorms }\end{array}$ & $\begin{array}{l}\text { Emergency Events } \\
\text { Database (2011) }\end{array}$ & + & 56.99 & 431.79 & 1014 \\
\hline Real GDP & $\begin{array}{l}\text { (Log) real GDP per capita } \\
\text { (constant } 2000 \text { US\$) }\end{array}$ & $\begin{array}{l}\text { World Bank } \\
\text { (2011) World } \\
\text { Development } \\
\text { Indicators }\end{array}$ & + & 9.009 & 1.337 & 988 \\
\hline Inflation rate & $\begin{array}{l}\text { Annual percentage change } \\
\text { in consumer price index }\end{array}$ & $\begin{array}{l}\text { World Bank } \\
\text { (2011) World } \\
\text { Development } \\
\text { Indicators }\end{array}$ & - & 1.418 & 1.147 & 961 \\
\hline Interest rate & Lending interest rates & $\begin{array}{l}\text { World Bank } \\
\text { (2011) World } \\
\text { Development } \\
\text { Indicators }\end{array}$ & $+/-$ & 1.640 & 0.781 & 777 \\
\hline $\begin{array}{l}\text { Health } \\
\text { expenditures }\end{array}$ & $\begin{array}{l}\text { Health expenditures as a } \\
\text { percentage of GDP }\end{array}$ & $\begin{array}{l}\text { World Bank } \\
\text { (2011) World } \\
\text { Development } \\
\text { Indicators }\end{array}$ & $+1-$ & 1.358 & 0.644 & 970 \\
\hline $\begin{array}{l}\text { Dependency } \\
\text { ratio }\end{array}$ & $\begin{array}{l}\text { The ratio of the population } \\
\text { under the age of } 15 \text { to the } \\
\text { population age } 15-65\end{array}$ & $\begin{array}{l}\text { World Bank } \\
\text { (2011) World } \\
\text { Development } \\
\text { Indicators }\end{array}$ & $+/-$ & 4.009 & 0.200 & 988 \\
\hline Risk & $\begin{array}{l}\text { Political risk index (lower } \\
\text { values represent greater } \\
\text { political risk) }\end{array}$ & $\begin{array}{l}\text { International } \\
\text { Country Risk } \\
\text { Guide (2010) }\end{array}$ & + & 4.312 & 0.1654 & 1013 \\
\hline
\end{tabular}

\section{About the Authors}

Chun-Ping Chang is Associate Professor at the Department of Marketing Management, Shih Chien University, Taiwan. He holds a Phd in Economics from the National Sun Yat-sen University, Taiwan. He is on the editorial board of Open Environmental Science. E-mail: cpchang@mail.kh.usc.edu.tw.

Aziz N. Berdiev is Assistant Professor at the Department of Economics, Bryant University, USA. He received his Phd in Economics from the University of Kentucky, USA. Prior to joining Bryant University in 2011, he taught courses at the College of Wooster and the University of Kentucky. E-mail: aberdiev@bryant.edu 